\title{
THE NATURE AND GROWTH OF VERTICAL
}

\section{SPECIALIZATION IN WORLD TRADE}

\author{
David Hummels \\ Jun Ishii \\ Kei-Mu Yi*
}

March 1999

\section{JEL code: F1}

\begin{abstract}
Dramatic changes are occurring in the nature of international trade. Production processes increasingly involve a sequential, vertical trading chain stretching across many countries, with each country specializing in particular stages of a good's production sequence. We document a key aspect of these vertical linkages - the use of imported inputs in producing goods that are exported - which we call vertical specialization. Using input-output tables from the OECD and emerging market countries we estimate that vertical specialization accounts for up to $30 \%$ of world exports, and has grown as much as $40 \%$ in the last twenty-five years. The key insight about why vertical specialization has grown so much lies with the fact that trade barriers (tariffs and transportation costs) are incurred repeatedly as goods-in-process cross multiple borders. Hence, even small reductions in tariffs and transport costs can lead to extensive vertical specialization, large trade growth, and large gains from trade. We formally illustrate these points by developing an extension of the Dornbusch-Fischer-Samuelson Ricardian trade model.
\end{abstract}

This paper is a revision and extension of "The Growth of World Trade" by Ishii and Yi (1997). Since then, the authors have benefited from comments by Marianne Baxter, Don Davis, Paul Evans, John Fernald, Raquel Fernandez, Caroline Freund, Jess Gaspar, Jim Harrigan, Jane Ihrig, Boyan Jovanovic, Chinhui Juhn, Bob King, Narayana Kocherlakota, Ayhan Kose, Michael Kouparitsas, Robert Lipsey, and Dana Rapoport, as well as seminar participants at New York University, University of Kentucky, Ohio State University, University of Virginia, Duke University, University of North Carolina, Federal Reserve Bank of Philadelphia, University of Toronto, Queen's University, University of Chicago GSB Brown Bag, 1997 NBER Summer Institute, and the 1998 Winter Econometric Society Meetings. The authors thank Josh Greenfield, Rema Hanna, Stefan Papaioannou, and Dana Rapoport for outstanding research assistance. The views expressed in this paper are those of the authors and are not necessarily reflective of views at the Federal Reserve Bank of New York or the Federal Reserve System.

*The University of Chicago, Stanford University, and the Federal Reserve Bank of New York. E-mail: david.hummels@gsbpop.uchicago.edu; jishii@leland.stanford.edu; kei-mu.yi@ny.frb.org. 


\section{INTRODUCTION}

While international trade has grown dramatically in the last half-century, equally dramatic changes have occurred in the nature of trade. One of the most important changes involves the increasing interconnectedness of production processes in a vertical trading chain that stretches across many countries, with each country specializing in particular stages of a good's production sequence. Facts about trade growth, such as the fifteen-fold increase in trade since 1950 or that trade has grown twice as fast as output during this period, are easy to come by. Indeed, they are often cited as the prima facie evidence of globalization. However, facts about the increased verticality in trade are more difficult to obtain. Other than case studies and some articles that examine trends in intermediate goods trade, there is little systematic evidence quantifying the extent of vertical linkages. ${ }^{1}$

This paper expands the set of systematic evidence that characterize verticality in trade. ${ }^{2}$ We develop a concept that we call vertical specialization, the key feature of which is that imported inputs are used to produce a country's export goods. ${ }^{3}$ Our concept emphasizes the twin notions that the production sequence of a good involves at least two countries, and that during this sequence, the good-in-process crosses at least two international borders. This latter notion highlights the sequential production, the multiple-border crossing, and the back-and-forth aspect of an increasing amount of international trade. For example, Japan now exports raw steel to Mexico, where the steel is stamped and pressed and then exported to the U.S., where it is manufactured into farm equipment, much of which is then exported again. From these notions we then develop measures of vertical specialization and apply them to industry-level data for

\footnotetext{
${ }^{1}$ See, for example, Feenstra and Hanson (1996) and Feenstra (1998). Yeats (1998) examines trends in a subset of intermediate goods trade, parts and components, trade. Campa and Goldberg (1997) calculate imported input shares for four countries over two decades.

${ }^{2}$ This paper is an extension and revision of Ishii and Yi (IY) (1997).

${ }^{3}$ The verticality in trade has been given many labels, including "slicing up the value chain" (Krugman, 1995), outsourcing (Feenstra and Hanson, 1996, 1997), disintegration of production (Feenstra, 1998), fragmentation of production (Deardorff, 1998) and (Jones and Kierzkowski, 1997), intra-product specialization (Arndt, 1997), and our preferred label, vertical specialization. Balasssa (1967) was perhaps the first to coin the phrase vertical specialization. Findlay (1978) also is an early user of the phrase.
} 
developed and emerging markets countries over time. Our primary measure, which we call VS, measures the value of imported inputs embodied in goods that are exported.

Our main data source is input-output tables, which provide industry-level data on imported inputs, gross output, and exports, the data that are needed to calculate our measures. We use the OECD input-output database, which covers 10 OECD countries, input-output tables from Ireland, Korea, and Taiwan, and data from Mexico's maquiladoras. These countries account for more than $60 \%$ of world trade. Our calculations show that, as of 1990, VS exports in these countries represented more than $21 \%$ of total exports, and had grown almost $30 \%$ since 1970. Moreover, VS growth accounts for $1 / 3$ or more of overall export growth. Under some plausible assumptions regarding countries not in our sample, we estimate vertical specialization in 1995 to be about $30 \%$ of world exports, representing growth of $40 \%$ since 1970 .

Several more facts emerge from a closer look at the data. Small countries tend to be more vertically specialized than large countries. The chemicals and machinery industries account for most of the growth in the VS shares of total exports. We also find that the use of imported inputs has grown most rapidly in export-oriented sectors. Finally, while vertical specialization in the OECD primarily involves other OECD countries, the U.S. has exhibited a trend towards vertical specialization with developing countries.

Why has vertical specialization grown so much and how does it account for so much overall trade growth? We believe an important driving force has been trade barrier reduction. Because the good-in-process crosses multiple borders, tariffs and transportation costs are incurred repeatedly. Hence, reductions in trade barriers yield a multiplied reduction in the cost of producing a good sequentially in several countries. Vertically specialized exports can thus expand greatly and account for a large fraction of overall export expansion.

To illustrate the above insight more formally, we develop and present a simple extension of the Dornbusch-Fischer-Samuelson (1977) continuum of goods Ricardian trade model. In the model, each good requires two stages of production. In equilibrium, a country may specialize in one stage and link sequentially with a partner country to produce the final good. The model shows two ways in which vertical specialization can lead to greater welfare gains from trade. The first is simply that specialization in individual stages of production facilitates a finer division of labor. The second way is more subtle. Since World War II, trade has grown rapidly while 
measurable trade barriers have fallen slowly. ${ }^{4}$ For tariffs and transport costs to explain the magnitude of trade growth without vertical specialization requires that foreign and domestic goods be close substitutes in consumption or production. ${ }^{5}$ Close substitutability implies that the gains from trade barrier reduction are relatively low. In contrast, because vertical specialization magnifies the effect of trade barrier reductions, large trade growth can occur even if foreign and domestic goods are relatively poor substitutes. For this reason, vertical specialization can imply larger welfare gains.

In section II, we present our vertical specialization concepts and measures, and compare them to other measures of verticality, such as intermediate goods trade. In section III, we present our calculations of vertical specialization levels and trends. Section IV gives our decomposition results and Section $\mathrm{V}$ discusses vertical specialization in the context of the extension of the Dornbusch-Fischer-Samuelson (1977) model. Section VI concludes.

\section{VERTICAL SPECIALIZATION: CONCEPTS AND MEASUREMENT}

\section{Concepts}

The key idea of verticality in trade is that to produce a final good, countries link sequentially. While there are probably many approaches to characterizing this linkage, our approach focuses on three conditions that we believe capture the central aspects of the sequential linkages. Vertical specialization occurs when:

[1] A good is produced in two or more sequential stages,

[2] Two or more countries provide value-added during the production of the good,

[3] At least one country must use imported inputs in its stage of the production process, and some of the resulting output must be exported. ${ }^{6}$

\footnotetext{
${ }^{4}$ Tariffs on manufactured goods have fallen by about 15 percentage points, and according to Hummels (1998a, 1998b), transportation costs have fallen little over the last thirty-five years.

${ }^{5}$ That is, the production possibilities frontier must be relatively flat for a small trade barrier reduction to induce a large trade volume change. A simple back-of-the-envelope calculation shows why. Tariffs and transportation costs have fallen by less than $1 / 2$ of 1 percentage point per year. On the other hand trade/GDP has grown by over $2.5 \%$ per year. This suggests elasticities of substitution of 5 and higher are needed to rationalize trade barrier reduction with trade growth. See Baier and Bergstrand (1997) for more careful elasticity estimates, and Yi (1999) for a calibration of trade growth with and without vertical specialization.

${ }^{6}$ We do not count border-crossings that are merely in transit shipments, e.g., Chinese goods going through Hong Kong's ports on their way to the U.S.
} 
Our third condition focuses on the sequential, 'back-and-forth' aspect of trade that recent anecdotal and case study evidence suggest has risen dramatically. ${ }^{7}$ This condition, which ensures that the good-in-process crosses multiple borders, is what distinguishes vertical specialization from other notions of verticality in trade, including intermediate goods trade. ${ }^{8}$ Note that all intermediate goods trade is consistent with [1] and [2]. However, only the subset of intermediate goods imports that become embodied in exported goods is consistent with all three conditions, and is therefore captured in vertical specialization.

There are three reasons why we believe our concept, vertical specialization, is a better characterization of verticality in trade than intermediate goods trade. First, there is a widespread perception - based on anecdotes and case studies, and the increasing importance of vertically integrated multinationals and of outsourcing - that verticality in trade is increasing. Yet, these new phenomena are not captured by trends in intermediate goods trade, because the share of intermediate goods in trade has actually declined. Grouping trade flows into capital, consumption, and intermediate categories using the United Nations "Broad Economic Categories" classification scheme, we find that the intermediate goods share of total trade fell from about $50 \%$ to $40 \%$ between 1970 and 1992, with even larger drops within the OECD. ${ }^{9}$

Second, as a practical matter, any classification of goods by product codes or descriptions into "intermediate" and "final" categories (including the one used above) is by necessity somewhat arbitrary. How should tires and engines, flour, and motherboards be classified? In some cases, they are intermediate goods (when they are purchased and used by firms to make cars, bread, and computers) and in some cases, they are final goods (when they are purchased by households). Many goods are like this. Also, Sanyal and Jones (1982) point out that even so-

\footnotetext{
${ }^{7}$ See IY (1997) and Hummels, Rapoport, and Yi (HRY) (1998) for case study evidence. Using a similar, but not identical, measure of vertical specialization, they calculate vertical specialization based trade in U.S.-Mexico maquiladora trade, Japan-Southeast Asia electronics trade, post-1965 U.s.-Canada auto trade, and Opel España's auto trade. Vertical specialization accounts for up to half of the relevant trade levels and trade growth.

${ }^{8}$ Another widely cited measure of verticality in international trade is outsourcing. Lawrence (1994), Slaughter (1995), Feenstra and Hanson (1996), and Berman, Bound, and Griliches (1994) examine different subsets of U.S. import data to construct measures of outsourcing (primarily measures of imported input use). These papers find that outsourcing in the U.S. is on the order of $10 \%$ to $15 \%$ of total imports. As we have indicated, the presence of imported inputs is necessary, but not sufficient, for non-zero VS.

${ }^{9}$ These data come from the Statistics Canada World Trade database, available from the NBER for years 1970 through 1992 with SITC codes concorded into the United Nations "Broad Economic Categories" classification scheme. This overall downward trend occurs whether or not we include oil in our definition of intermediate goods. More details are provided in Appendix I. Yeats (1998) shows that parts and components trade, a subset of intermediate goods trade, has grown as a share of total trade.
} 
called final goods need marketing-and-distribution services added to them when they are imported so that, in effect, all traded goods are intermediate goods. Our concept, on the other hand, does not rely on such classification schemes; rather, it builds on an input-output structure that indicates where a country's industries acquire their inputs and where these industries sell their outputs.

Third, as a theoretical matter, the workhorse models of final goods trade - Ricardian, Heckscher-Ohlin, and monopolistic competition - can easily be re-interpreted as models of intermediate goods trade, where these intermediate goods are costlessly assembled into nontraded final goods. In this sense, intermediate goods are not conceptually distinct from final goods. Vertical specialization, on the other hand, leads to a useful categorization of trade models: a) models in which only one stage of production - an intermediate stage or the final stage, but not both - is traded, and b) models in which two or more stages are traded. The workhorse models, as well as Sanyal and Jones (1982), are all in the former category, but models such as Ethier (1982), Deardorff $(1979,1998)$, and Feenstra and Hanson $(1996,1997)$ are in the latter category. This taxonomy is helpful because only the latter models build in our core idea that tariffs and transportation costs penalize vertically specialized goods each time they cross a border.

For these reasons, we conclude that to characterize the increasing verticality in international trade, the relevant distinction is not intermediate goods versus final goods. The relevant distinction is between goods where multiple stages are traded (vertical specialization) and goods where only one stage is traded.

\section{Measurement}

Figure 1 illustrates an example of a vertical specialization chain involving three countries. Country 1 produces intermediate goods and exports them to Country 2. Country 2 combines the imported intermediates with capital and labor (value-added), and domestically produced intermediate inputs to produce a final good (gross output). Finally, Country 2 exports some of the final good to Country 3. Our primary measure of vertical specialization, which we call VS, captures Country 2's involvement in this process: 


$$
\begin{aligned}
\text { VS } & =\left(\frac{\text { imported intermediates }}{\text { gross output }}\right) \cdot \text { exports } \\
& =\left(\frac{\text { exports }}{\text { gross output }}\right) \cdot \text { imported intermediates }
\end{aligned}
$$

Simply put, VS is the imported input content of exports, or equivalently, foreign value-added embodied in exports. The first term in equation (1) expresses the contribution of imported inputs into gross production. Multiplying this ratio by the amount that is exported provides a dollar value for the imported input content of exports. If Country 2 uses no imported inputs, or if it does not export its output, $\mathrm{VS}=0$.

To measure aggregate VS using sector-level data, subscript the variables in equations (1) and (1a) by sector i and country k. Aggregate VS is simply the sum of VS for each sector, $\mathrm{VS}_{\mathrm{k}}=\sum_{i} \mathrm{VS}_{\mathrm{ki}}$. Because we are interested in changes in the composition of trade, we normalize VS by total exports. Expressing country k's VS as a share of total exports:

$$
\frac{\mathrm{VS}_{\mathrm{k}}}{\mathrm{X}_{\mathrm{k}}}=\frac{\sum_{\mathrm{i}} \mathrm{VS}_{\mathrm{ki}}}{\sum_{\mathrm{i}} \mathrm{X}_{\mathrm{ki}}}
$$

where $\mathrm{X}$ denotes exports. Note that aggregate VS as a share of exports increases if the use of imported inputs increases in the most export-intensive sectors and/or if exports increase in the sectors using imported inputs most intensively. This can occur even if the share of intermediate goods in imports is falling.

To empirically implement our VS measure, we would ideally use data on the production process and direction of trade flow for every stage of each good that is traded. These data are impossible to obtain except on a case-by-case basis. Instead, we rely primarily on input-output tables. Our input-output (I-O) tables include sector-level data on inputs (distinguishing foreign and domestic sources), value-added, gross output, and exports. This allows a straightforward calculation of (1), (1a) or (1b) for each industry and for the country as a whole. In matrix notation, the formula for VS as a share of total exports for country k (the equivalent of (1b)) is:

$$
\mathrm{VS}_{\mathrm{k}} / \mathrm{X}_{\mathrm{k}}=\mathbf{u} \mathbf{A}^{\mathbf{M}} \mathbf{X} / \mathrm{X}_{\mathrm{k}}
$$


where $\mathbf{u}$ is a $1 \mathbf{x} \mathbf{n}$ vector of 1 's, $\mathbf{A}^{\mathbf{M}}$ is the $\mathrm{n} \mathbf{x} \mathrm{n}$ imported coefficient matrix, $\mathbf{X}$ is an $\mathrm{n} \mathbf{x} 1$ vector of exports, $X_{k}$ is total country exports, and $n$ is the number of sectors. Element $a_{i j}$ of $\mathbf{A}^{\mathbf{M}}$ denotes the imported inputs from sector $\mathrm{i}$ used to produce one unit (expressed in any common currency) of sector j's output.

We extend our measure in three ways. First, an attractive feature of I-O tables is they allow us to calculate the value of imported inputs used indirectly in production of an exported good. That is, imported inputs may be used in one sector, whose outputs are employed in a second, then a third, and eventually embodied in an export good. Imported inputs are allowed to circulate through several stages of the domestic economy before 'exiting' as an export. In terms of equations (1) and (1a) above, the imported intermediates term would include all direct and indirect (embodied in domestic inputs) imported inputs. The more general way to compute VS as a share of total exports for country $\mathrm{k}$ with these tables is:

$$
\mathrm{VS}_{\mathrm{k}} / \mathrm{X}_{\mathrm{k}}=\mathbf{u} \mathbf{A}^{\mathrm{M}}\left[\mathbf{I}-\mathbf{A}^{\mathbf{D}}\right]^{-1} \mathbf{X} / \mathrm{X}_{\mathrm{k}}
$$

where $\mathbf{u}$ is a $1 \times \mathbf{x}$ vector of $1^{\prime}$ s, $\mathbf{A}^{\mathbf{M}}$ is the $\mathrm{n} \times \mathrm{n}$ imported coefficient matrix, $\mathbf{I}$ is the identity matrix, $\mathbf{A}^{\mathbf{D}}$ is the $\mathrm{n} \mathbf{x} \mathrm{n}$ domestic coefficient matrix, $\mathbf{X}$ is an $\mathrm{nx} 1$ vector of exports, $\mathrm{X}_{\mathrm{k}}$ is total country exports, and $\mathrm{n}$ is the number of sectors. ${ }^{10}\left[\mathbf{I}-\mathbf{A}^{\mathbf{D}}\right]^{-1}$ is the term that captures allowing the imported input to be embodied in a domestic output at the $2^{\text {nd }}, 3^{\text {rd }}, 4^{\text {th }}, \ldots$ stage before it becomes embodied in the good that it is exported. It is the matrix analogue of an infinite geometric sum. We use (3) as our main measure of VS. Note that this formulation allows the goods to circulate through all sectors of the economy, including the service sectors.

Second, in our base calculations the only imports that enter into (3) are intermediate goods. For many countries, capital goods are a large fraction of imports. In the U.S. in 1997, non-automotive capital goods represented about $30 \%$ of all merchandise imports. Logically, one can think of capital goods as a type of intermediate good in the sense that rental services from the capital become embodied in the goods that are produced from it. Hence, we also compute a

\footnotetext{
${ }^{10}$ Development economists have used (3), which they also call the import content of exports. See for example, Chenery, Syrquin, and Robinson (1987). However, their interest was traditionally with balance of payment issues, not the extent of vertical specialization, or its implications for trade growth and gains from trade.
} 
variation of VS - called VSK - that calculates the imported capital service content of exports. These calculations are contained in Appendix II.

Third, recalling Figure 1, we have focused on Country 2's participation (the import content of exports) in vertical specialization because our data are especially well-suited to measuring this transaction. We could also measure Country 1's participation, the value of exports that are embodied in a second country's export goods. We call this measure VS1. This is of independent interest because when countries specialize in stages of production, VS1 can be high when VS is low, as is the case for Country 1. A complete picture of vertical specialization involves both measures. However, VS1 is more difficult to measure than VS, because it requires matching bilateral trade flow data to the input-output relations. Appendix III provides a broad, relatively crude VS1 calculation for the OECD database countries, and a more narrow calculation involving U.S. trade with Canada and Mexico. ${ }^{11}$

The relatively aggregate sectoral data from the input-output tables can lead to underestimates or overestimates of the true level of VS. If, within a sector, there is a positive (negative) correlation between exports and the imported inputs/gross output ratio, the sector-level data will underestimate (overestimate) the true level of VS. Suppose, for example, that a sector produces just two goods. One good uses imported intermediate inputs but is not exported. The other good uses no imported inputs but is exported. In this case, actual VS would be zero, yet at the sector level we would calculate a positive value. On the other hand, suppose that the first good relies heavily on imported intermediate inputs and is heavily exported, and the second good uses no imported inputs and is not exported. Then, at the sector level, we would underestimate VS. We cannot ascertain which case is more likely, but using our OECD data to compare an aggregate VS estimate to a sector-level VS estimate suggests that higher aggregation tends to lead to an underestimate of VS. ${ }^{12}$

\footnotetext{
${ }^{11}$ While our measures of vertical specialization imply that a good-in-process crosses at least two borders, we cannot determine the average number of border-crossings. The number of border-crossings matter because it gives the "multiplier" trade effect that results from a given change in trade barriers. Also, we are only able to compute VS with merchandise trade; hence, we ignore trade in R\&D or multinational headquarters services. This may be an important channel through which vertical specialization operates.

${ }^{12}$ That is we compare the ratio of country-level imported inputs to country-level gross output with the sector-level calculation (1b). For the U.S. in 1990, using sector level data to calculate the VS share yields a value of $10.8 \%$. The aggregate ratio of imported inputs to total gross output is $6.0 \%$ so using aggregate data understates the U.S. VS share by $44 \%$. Similar values are found for other countries. This suggests our estimates are a lower bound for VS. Of
} 


\section{VERTICAL SPECIALIZATION EXPORTS: DATA, LEVELS, AND TRENDS}

\section{Data Sources}

The primary source of our input-output tables is the OECD Input-Output Database, which contains tables for ten countries - the G-7 nations, plus Australia, Denmark, and the Netherlands - for several years between 1968 and $1990 .{ }^{13}$ The major advantage of this data set is that it provides a consistent set of tables to facilitate comparisons across countries and over time. The ten countries account for about two-thirds of world GDP and more than 55\% of world trade. The tables divide output into thirty-five sectors, including eleven service sectors and twenty-four goods-producing sectors, of which twenty-two are manufacturing. The concentration on manufacturing sectors is important because they increasingly dominate world trade. ${ }^{14}$ For each country, we focus on the goods sectors.

We also employ input-output tables for Ireland (1964, 1975, 1990), Korea (1963, 1970, 1990, 1993), and Taiwan (1981, 1994). These were obtained primarily through these countries' national statistical agencies or Central Banks. For Mexico, we use data on maquiladoras, including imported inputs, gross output and exports. Mexico's maquiladoras are foreign-owned production plants that complete processing or secondary assembly of imported components explicitly for export. ${ }^{15}$ More details on these data sources are discussed in Appendix I.

\section{VS Levels and Trends: OECD Input-Output Database}

Hereafter, we will use "VS export share of total exports", "VS share of exports", and "VS share" interchangeably. Table 1 presents aggregate VS shares of exports for each country (initial year and final year) in our OECD database, and reveals substantial cross-country variation. The U.S., Japan and Australia have VS shares of about 5\%-10\%, while Canada, Denmark, and the

course, comparing one aggregate sector to 24 broad sectors need not imply the same result as comparing 24 sectors to even more sectors.

${ }^{13} \mathrm{HRY}$ (1998) also looks at this database. HRY is an outgrowth of research embodied in IY and in this paper.

${ }^{14}$ In 1970, manufacturing accounted for about 60 percent of world merchandise trade; in 1994, it accounted for about 75 percent. (UNCTAD, 1995, 1992)

${ }^{15}$ Maquiladora plants benefit from Mexican laws that exempt from Mexican tariffs parts and materials imported by Mexico for use in maquiladoras. Also, U.S. components of maquiladora-made goods exported back to the U.S. are exempt from U.S. tariffs (under Harmonized Tariff System items 9802.00.60 and 9802.00.80). U.S. firms own the vast majority of maquiladoras, although there is increasing ownership by firms from Japan, Korea, and some European nations. While maquiladoras are now allowed to sell some output domestically, reports of factory managers in Mexico suggest that virtually all production is still exported to the U.S. We thank Lucinda Vargas for this latter information. See HRY (1998) for more background information on the maquiladoras. 
Netherlands have VS shares around 30\%-35\%. Smaller countries have higher VS shares: the sample correlation between the VS share of exports and GDP is -0.65 in the final year. ${ }^{16}$

The last row of Table 1 gives the growth of the VS shares from the first to the last year of the sample. For every country but Japan, the VS share grew between the first and last year of the sample. In Australia, Canada, France, the U.K., and the U.S., VS grew 25\% or more. The U.S. had the fastest VS growth rate, 3.4\% annualized between 1972 and 1990. The top panel of Figure 2 illustrates the growth in the VS shares for the U.S. We express VS as a share of both total exports and total imports to contrast the growing VS shares with the declining U.S. intermediate goods trade shares, illustrated in the bottom panel of Figure 2.

Using the final year for each country, and aggregating across countries, we calculate VS in the entire ten-country sample to be $20.0 \%$ of total exports. Using the earliest year for each country, we calculate VS to be $16.2 \%$ of total exports. ${ }^{17}$ This is an increase of about $24 \%$ over a fifteen-to-twenty year period.

More detailed VS share calculations for all 24 goods sectors is presented in Table 2. Two broad facts emerge. First, sector-level VS shares vary widely across sectors within a country. For example, in Japan in 1990, the VS shares range from 6\% in agriculture, forestry and fishing to $51 \%$ in petroleum products. Second, VS shares vary widely across countries within a sector. In motor vehicles, VS shares ranges from 9\% in Japan (1990) to 51\% in Canada (1990), no doubt because of the tight integration of the US and Canadian auto sectors. However, sectors with low VS shares tend to be relatively resource and raw material intensive.

\section{VS Levels and Trends: Ireland, Korea, Taiwan, and Mexico}

The small countries in our OECD sample have the largest VS shares. Because the rest of the world consists primarily of small countries, we would expect to find relatively large VS shares for countries outside our OECD database. To verify this, we calculate VS for Ireland, Korea, Taiwan, and Mexico. The calculations for Ireland, Korea, and Taiwan are listed in Table 3. In all three cases, VS shares are quite high, (around one-third, similar to Netherlands in the OECD database) but have increased little over time. This is surprising for Ireland given the

\footnotetext{
${ }^{16}$ The GDP data are from IMF International Financial Statistics. The correlation between population and VS share is -0.69 .

${ }^{17}$ For Italy we have only one year of data (1985). We assume that Italy's VS share is 0.2 in 1970 , which is similar to the VS shares in France, Germany, and the U.K. around that time.
} 
recent surge in multinational activity there during the last two decades. ${ }^{18}$ However, these three countries' exports as a share of world exports has increased by a factor of 9 between 1963 and 1993, implying that their VS exports as a share of world exports has also increased by about an order of magnitude.

For Mexico we use data on maquiladora imports, gross production, and exports instead of I-O tables. Our calculations indicate that the VS share of exports is large and has increased significantly. Figure 3 shows that between 1979 and 1984, VS as a share of total Mexican merchandise exports was about $10 \%$. But this share rose rapidly subsequently; as of 1997, it was $32 \%$ or $\$ 35$ billion. This is a lower bound because there is also VS originating from nonmaquiladora channels. For example, the U.S. International Trade Commission estimates that non-maquiladora activity in 1996 led to an additional $\$ 8$ billion of Mexican exports to the U.S. Assuming that the imported input content for these exports was about 80\%, then VS exports for this activity is roughly $\$ 6.4$ billion. $^{19}$ Added to our maquiladora VS, our total VS for 1996 would be $36.5 \%$ of total exports. Assuming that an equal amount of this type of nonmaquiladora activity occurred the following year, then Mexico's VS share for 1997 would be about $40 \%$.

\section{Linking VS growth to Trade Growth}

We use growth accounting to address the sources of growth in overall exports (as a share of gross output). We decompose exports into VS exports and other exports (this is equivalent to decomposing exports into foreign value-added embodied in exports and domestic value-added embodied in exports). ${ }^{20}$ The top panel of Table 4 presents the results for our OECD database sample. For Canada and the Netherlands, roughly 50 percent of the growth of exports is accounted for by growth in VS. In Denmark, France, and the United Kingdom, growth in VS accounts for more than 30 percent of export growth. Only in Japan does growth in VS exports account for a small fraction of total export growth.

\footnotetext{
${ }^{18}$ According to Barry and Bradley (1997, p. 1798) "almost $60 \%$ of gross output and $45 \%$ of employment in manufacturing is in foreign-owned export-oriented firms".

${ }^{19}$ Our $80 \%$ number is an informal estimate by Ralph Watkins, chief of the Miscellaneous Manufacturing branch of the USITC. This value is somewhat lower than the imported input content for the maquiladoras.

${ }^{20}$ Strictly speaking, the imported input content of exports, or VS, is equal to the foreign valued-added embodied in exports whenever there are only two stages of production. If there are more than two stages of production, and if a country re-imports some of its own value-added to use as inputs into other goods that are then exported, then foreign value-added is less than the imported input content of exports.
} 
We perform a similar exercise for Ireland, Korea, Mexico, and Taiwan. (In some cases we use GDP instead of gross output, due to lack of data). ${ }^{21}$ The bottom panel of Table 4 presents our results. In all cases growth in VS accounts for more than $30 \%$ of the growth in the export share of output. For Mexico between 1979 and 1994, and for Taiwan between 1961 and 1994, VS accounts for more than $50 \%$ of export growth.

\section{Vertical Specialization: Estimates for the World}

Above, we calculated VS shares for each country in our OECD database, as well as for several other countries. We now present three calculations for world VS exports as a share of world exports. Each calculation is an export-weighted average of the country VS shares. ${ }^{22}$ In our first calculation, we examine only the countries in the OECD database, as well as Ireland, Korea, Mexico, and Taiwan. These fourteen countries accounted for $63 \%$ of world exports in 1990. The results are listed in column 1 of Table 5. We find that VS was $16.5 \%$ of total exports in 1970 and $21.1 \%$ of total exports in 1990 , a $28 \%$ increase in two decades. The column also gives an extrapolated VS share estimate of $22.2 \%$ for 1995 , which would represent a $35 \%$ increase over a twenty-five year period.

In our second calculation, we add the rest of Europe and other East Asian emerging market countries (China, Hong Kong, Indonesia, Malaysia, Singapore, and Thailand) to our fourteen countries. The set of countries in this expanded sample accounted for $82 \%$ of world exports in 1990. We assume that the VS share for the rest of Europe, including Ireland, is 0.25 in 1970 and 0.3 in 1990 and 1995. For the East Asian emerging market countries, including Korea and Taiwan, we assume that the VS share is 0.25 in 1970 and 0.35 in 1990 and 1995. Based on these assumptions, column 2 of Table 4 shows that the world VS share of export rises from $18.0 \%$ in 1970 to $25.0 \%$ in 1995 , almost a $40 \%$ increase.

In our third calculation, we add the rest of the world to our second sample. Most of these other countries are primarily commodity exporters. Based on case study evidence suggesting that the imported input share of gross output tends to be between 5\% and 15\% in these sectors, we assume the VS share is 0.1 in 1970 and constant over time. ${ }^{23}$ Column 3 presents our estimate for

\footnotetext{
${ }^{21}$ We draw our Taiwan 1961 VS number from Chenery, Robinson, Syrquin (1987, p. 217).

${ }^{22}$ More details on the calculations are provided in the notes to Table 4.

${ }^{23}$ See, for example, Birmingham, Neustadt, and Omaboe (1966), Baer (1995), and Pearson and Cownie (1974).
} 
the world VS share incorporating this assumption. The world VS share of exports rises from $15.9 \%$ in 1970 to $22.7 \%$ in 1995 , more than a $40 \%$ increase.

The above calculations focused on VS only. In Appendix II and III we also provide estimates for VSK (imported capital inputs embodied in exports) and VS1 (exports embodied in a second country's exports) for the 10 countries in the OECD database. Assuming that VSK+ VS1 equals $10 \%$ of exports in 1995, (and using the fact that these 10 countries account for 55\% of world exports in that year) we get an overall estimate of vertical specialization in 1995 equal to $28 \%-30 \%$ of world exports.

\section{VERTICAL SPECIALIZATION EXPORTS: DECOMPOSITIONS}

Having examined the broad levels and trends in vertical specialization, in this section we provide decompositions that address two issues. First, how much of the variation in vertical specialization over time and across countries is due to variation in sectoral VS shares or variation in the sector composition of overall exports? Second, what can we say about the imported input and geographic orientation of vertical specialization?

\section{Decomposing Variation in Vertical Specialization Over Time and Across Countries}

Following conventional "within" and "between" accounting, we decompose changes in aggregate VS into changes in sector VS intensity (the sector VS share of sector exports) and changes in the sector composition of overall exports. See Appendix IV for details on the decomposition. For expositional convenience, we aggregate our sector-level changes into changes in three broad industries, chemicals, machinery, and other, as listed in Table 2.

The left side of Table 6 gives the overall VS share of exports, as well as the VS shares for the three industry groups in the first and last years of our sample for each country. The right side of Table 6 presents the growth decompositions. Focusing first on the "Total" rows, we see that changes in vertical intensity across all sectors account for most of the growth in overall VS share. Changes in the sector composition of overall exports play a small role. With the exception of Japan, increases in vertical intensity explain three-quarters or more of the increase in overall vertical specialization.

Examining the "Total" column gives us the breakdown by sectors. In six of the countries (all but Australia, Netherlands and Japan), we find that machinery accounted for at least 62 
percent of the increase in the VS share of exports between the first and last year. In every country except Australia and Japan, machinery and chemicals accounted for more than 74 percent of the growth in the VS share. ${ }^{24}$ Finally, we see that these two broad sectors contribute primarily through increases in their vertical intensity. These sectors accounted for the majority of manufacturing export share increases from the 1970s to the 1980s. Our results indicate that the sectors that account for overall VS share growth are the same ones that account for overall export growth.

We employ similar decompositions to assess whether cross-country variation in VS shares is due to sector vertical intensity or sector export composition. In this exercise, we examine differences relative to a "representative" country, constructed by taking a simple average of sector vertical intensity and sector composition over all countries. Table 7 presents the results. We again see that differences in vertical intensity account for most of the crosscountry variation in VS shares. Differences in sector composition play a fairly minor role. However, unlike in the growth decompositions, we do not find that the chemicals and machinery industries account for most of the cross-country variation in VS shares.

A direct comparison of Canada relative to the U.S is instructive. The VS share is much higher in Canada (27 percent versus 11 percent, in 1990). Virtually all of this difference (99 percent) is due to greater sector vertical intensity in Canada. In particular, greater vertical intensity in the machinery sector accounts for three-quarters of the overall VS share difference, and greater vertical intensity in the motor vehicles industry alone accounts for half. ${ }^{25}$

The growth and cross-country decompositions deliver two main lessons. Variation in sectoral VS intensity accounts for almost all of the overall VS share variation over time and across countries. In most of the countries, the chemicals and machinery industries account for most of the VS share growth over time.

\section{Vertical Specialization: Orientation}

We now examine the imported input and geographic orientation of vertical specialization. Tables 1 and 2 indicate that VS has grown for nearly every country and every sector in our

\footnotetext{
${ }^{24}$ In Japan, the overall VS share declined. Chemicals and Machinery VS shares grew, but it was not enough to offset the decline in the "other" VS share. Results for Japan are then consistent with other countries - vertical specialization in chemicals and machinery is growing, and accounting for a major portion of overall VS share growth. Most of the VS share growth in Australia came from mining and quarrying, and non-ferrous metals.

${ }^{25}$ This is consistent with the U.S.-Canada auto case study in IY (1997) and HRY (1998).
} 
sample. Clearly, increased use of imported inputs has played a large role. But have imported inputs grown faster for sectors that are export-oriented or for sectors that produce mostly for domestic consumption? To address this question, we note that all production is either consumed domestically or exported. We then calculate the value of imported inputs consumed domestically as the difference between total use and use for export goods, i.e., VS. ${ }^{26}$ Table 8 shows the changes in the orientation of imported input use between the first and last years of our OECD sample. Use of imported inputs in domestic consumption has grown (everywhere but Japan), but their use in export sectors has grown faster. Hence, the increase in VS shares represents more than a general increase in reliance on imported inputs. ${ }^{27}$

Finally, we examine geographic patterns in vertical specialization. Is vertical specialization, like most trade, primarily north-north? Or does it more intensively involve northsouth trade, as with the Mexican maquiladoras? This question is especially relevant to the debate on how verticality in trade has affected wages. Economists have argued that outsourcing allows firms to separate the skilled-labor intensive stages from the unskilled-labor intensive stages of production. The unskilled-labor stages are outsourced, reducing the demand for domestic unskilled labor, leading to a widening of the wage gap between skilled and unskilled labor. ${ }^{28}$

To calculate the geographic orientation of vertical specialization we combine our OECD database input-output data with bilateral trade data taken from the Statistics Canada World Trade Database. Details on this calculation are provided in Appendix V and are briefly summarized here. Using both data sets we separate gross output into value-added, domestic inputs, imported inputs from the north (OECD), and imported inputs from the south (non-OECD). A similar calculation on the export side allows us to determine the direction (domestic consumption versus exported north versus exported south) that the imported inputs are sent. This allows us to determine the approximate bilateral orientation of vertical specialization for each country, which

\footnotetext{
${ }^{26}$ At the sector level we do not directly observe whether imported inputs are destined for goods consumed domestically or exported. Our calculation uses variation across sectors in imported input usage and export intensity to calculate an aggregate orientation.

${ }^{27}$ A related question asks whether the growth in imported input use represents a shift toward greater use of inputs from all sources (a growing gross output/value added ratio) or a shift away from domestically produced inputs. Examining the OECD input-output tables we find there is very little variation in the aggregate gross output/value added ratio over time and across countries. To the extent that the ratio does vary, the difference is made up entirely by imported, not domestic, inputs.
} 
we summarize into N-N, N-S, S-N, and S-S groups. S-S, for example, represents imported inputs from the south that are used by the OECD country to produce goods that are exported back to the south. ${ }^{29}$

Table 9 presents our calculations for each country using the initial year and final year of data. The vertical specialization orientation numbers are quite similar to the overall trade orientation for these countries. ${ }^{30}$ For both years, the most common geographic pattern of vertical specialization involves northern imported inputs being transformed into export goods destined for other northern countries. South-south vertical links are in general the smallest. Canada's vertical specialization is almost exclusively north-north, while Japan's is split evenly among the four origin/destination categories. Comparing the initial year to the final year, we see that the only country to have a substantial decline in its north-north vertical orientation is the U.S., which fell from $49 \%$ to $41 \%$. The share of total U.S. vertical specialization consisting of imports originating from the south rose from $26 \%$ to $37 \%$. This is consistent with the outsourcing explanations of the increase in U.S. wage inequality.

\section{A MODEL OF VERTICAL SPECIALIZATION}

In order to more formally link the increase in vertical specialization to gains from trade and the growth of trade, we present a stylized Ricardian model of trade that extends the Dornbusch, Fischer, Samuelson (DFS) (1977) model. As in DFS, there are two countries, a continuum of goods on the unit interval, and one factor of production (labor). Both countries are capable of producing all goods.

\footnotetext{
${ }^{28}$ See footnote 7 for references to the outsourcing debate. In addition to widening the skilled wage gap, outsourcing will tend to increase the use of skilled labor in the stages of production that remain in the northern country. This mimics the effects of skill-biased technological change.

${ }^{29}$ This imputation requires the strong assumption that goods within a sector are homogeneous, and so will miss differences in input types across north versus south origins. Suppose Southern inputs are combined with domestic value added and exported, while Northern inputs are used only in goods that are produced for domestic consumption. Northern inputs are not vertically specialized but we will measure them as such.

${ }^{30} \mathrm{~A}$ rough comparison can be made by multiplying the northern share of trade in total imports and exports. For the U.S., this figure is 38 percent, slightly lower than the N-N vertical specialization share. Were there no differences in north versus south sector composition and their use in vertically specialized goods, the geographic orientation of vertical specialization will exactly match the geographic orientation of overall trade.
} 
The key point of departure is the production technology. Producing each final good requires two stages. ${ }^{31}$ The first-stage output $Y_{1}(\mathrm{z}), \mathrm{z} \in[0,1]$, is produced from labor alone. The second stage combines the first-stage output $\mathrm{Y}_{1}(\mathrm{z})$ with labor to produce the final good, $\mathrm{Y}(\mathrm{z}){ }^{32}$ We assume the second stage production function is Leontieff. Both stages assume constant unit labor requirements. Let $\mathrm{a}_{1}(\mathrm{z})$ and $\mathrm{a}^{*}{ }_{1}(\mathrm{z}), \mathrm{z} \in[0,1]$, denote the first-stage unit labor requirements for the home and foreign country respectively, and similarly, $\mathrm{a}_{2}(\mathrm{z})$ and $\mathrm{a}_{2}{ }_{2}(\mathrm{z}), \mathrm{z} \in[0,1]$, are the second-stage unit labor requirements. $\quad \mathrm{A}_{1}(\mathrm{z})=\mathrm{a}{ }_{1}(\mathrm{z}) / \mathrm{a}_{1}(\mathrm{z})$, and $\mathrm{A}_{2}(\mathrm{z})=\mathrm{a}_{2}{ }_{2}(\mathrm{z}) / \mathrm{a}_{2}(\mathrm{z})$, are the relative unit labor requirements for stage-one and stage-two production.

With two countries and two stages of production, there are four possible production techniques or specialization patterns for each good:

HH: Home country produces both stages.

HF: Home country produces first stage; foreign country produces second stage.

FH: Foreign country produces first stage; home country produces the second stage.

FF: Foreign country produces both stages.

Suppose good $\mathrm{z}$ is produced by pattern HF. Then,

$$
\begin{aligned}
& \mathrm{Y}_{1}(\mathrm{z})=\mathrm{L}_{1}(\mathrm{z}) / \mathrm{a}_{1}(\mathrm{z}) \\
& \mathrm{Y}^{*}(\mathrm{z})=\min \left[\mathrm{Y}_{1}(\mathrm{z}), \mathrm{L}_{2}{ }_{2}(\mathrm{z}) / \mathrm{a}_{2}{ }_{2}(\mathrm{z})\right]
\end{aligned}
$$

Note that if $\mathrm{z}$ is produced by $\mathrm{HH}$ or $\mathrm{FF}$, the production technology is the essentially the same as the familiar one-stage formulation. For technique $\mathrm{HH}$, we have $\mathrm{Y}(\mathrm{z})=\mathrm{L}(\mathrm{z}) / \mathrm{a}(\mathrm{z})$, where $\mathrm{L}(\mathrm{z})=$ $\mathrm{L}_{1}(\mathrm{z})+\mathrm{L}_{2}(\mathrm{z})$, and $\mathrm{a}(\mathrm{z})=\mathrm{a}_{1}(\mathrm{z})+\mathrm{a}_{2}(\mathrm{z})$. Vertical specialization occurs when the home country exports intermediate goods to the foreign country, which uses them to produce goods it exports, (technique HF), or when the foreign country exports intermediate goods to the home country, which uses them to produce goods it exports (technique FH).

As in the one-stage model, comparative costs determine the specialization pattern. Under free trade, HF is used to produce good $\mathrm{z}$ when:

\footnotetext{
${ }^{31}$ Our model formalizes some of the discussion in Jones and Kierzkowski (1990). There are other models of vertical specialization related to the DFS model. Among the first were Dixit and Grossman (1982) and Sanyal (1983). In these models, there are only two goods, but a continuum of stages for at least one of them. More generally, many trade models that allow for trade in both intermediate goods and final goods, such as Ethier (1982) or Deardorff $(1979,1998)$, can be models in which vertical specialization exists. Some of the recent models of outsourcing (such as Feenstra and Hanson $(1996,1997))$ and vertical FDI have vertical specialization, as well.
} 


$$
\begin{aligned}
& w_{1}(z)+w^{*} a^{*}(z)<w_{1}(z)+w a_{2}(z), \\
& w_{1}(z)+w^{*} a^{*}{ }_{2}(z)<w^{*} a^{*}{ }_{1}(z)+w a_{2}(z), \text { and } \\
& w^{*} a_{1}(z)+w^{*} a^{*}{ }_{2}(z)<w^{*} a^{*}{ }_{1}(z)+w^{*} a^{*}(z),
\end{aligned}
$$

where $\mathrm{w}$ and $\mathrm{w}^{*}$ are the home and foreign wages, expressed in a common unit.

With no loss of generality, we order the goods according to declining home country comparative advantage in stage 1 production: $A_{1}^{\prime}(\mathrm{z})<0$. For stage 2 production, we examine two special cases. In the first case, illustrated in the top panel of Figure 4, we assume the comparative advantage ordering is the same as in stage $1: \mathrm{A}_{2}^{\prime}(\mathrm{z})<0$. We also assume the home country is always relatively more productive in stage 1 than in stage $2: \mathrm{A}_{1}(\mathrm{z})>\mathrm{A}_{2}(\mathrm{z}), \forall \mathrm{z} \in$ $[0,1]$. In this case, the equilibrium relative wage will divide the $[0,1]$ interval into three regions, where $\mathrm{Z}_{1}$ and $\mathrm{z}_{\mathrm{h}}$ are the cutoffs determining the pattern of stage- 1 and stage- 2 specialization. $\mathrm{z}_{1}$ is defined by $\mathrm{w} \mathrm{a}^{*}{ }_{2}\left(\mathrm{z}_{1}\right)=\mathrm{wa}_{2}\left(\mathrm{z}_{1}\right)$, and $\mathrm{z}_{\mathrm{h}}$ is defined by $\mathrm{w}^{*} \mathrm{a}^{*}{ }_{1}\left(\mathrm{z}_{\mathrm{h}}\right)=\mathrm{wa}_{1}\left(\mathrm{z}_{\mathrm{h}}\right)$. For goods in the first region, $\left[0, z_{1}\right]$, the home country produces both stages and exports some of the final good output to the foreign country (technique $\mathrm{HH}$ ). Goods in the second region, $\left[\mathrm{z}_{1}, \mathrm{z}_{\mathrm{h}}\right]$, use technique $\mathrm{HF}$. The home country produces the first stage and exports all production to the foreign country. The foreign country produces the second stage using the first-stage output of the home country, and exports some of the second-stage output back to the home country. This is the region of vertical specialization. For goods in the third region, $\left[\mathrm{z}_{\mathrm{h}}, 1\right]$, the foreign country produces both stages and exports some of the final good output to the home country (technique FF).

In the second case, illustrated in the bottom panel of Figure 4, the comparative advantage ordering is exactly the opposite as in stage $1: \mathrm{A}_{2}^{\prime}(\mathrm{z})>0$. We illustrate a scenario in which goods on the interval $[0, \mathrm{z} 1]$ are produced by technique HF, goods on the interval $[\mathrm{z} 1, \mathrm{z} 2]$ are produced by technique FF, and goods on the interval $[\mathrm{z} 2,1]$ are produced by technique FH. In section II, we distinguished two ways in which an exported good can be involved in vertical specialization. The exports can embody imported inputs (VS) or the exports themselves can be used as inputs in foreign production and export (VS1). This case has both types for both countries. For the home country, goods produced and exported with technique HF count as VS1, and the imported inputs embodied in goods produced and exported with technique FH count as VS. For the foreign

\footnotetext{
${ }^{32}$ For each $\mathrm{z}$, intermediate good $\mathrm{Y}_{1}(\mathrm{z})$ can only be used to produce final good $\mathrm{Y}(\mathrm{z})$.
} 
country, goods produced and exported with FH count as VS and imported inputs embodied in goods produced and exported with HF count as VS1. Note that in a two-country setup foreign's VS1 equals home's VS and vice versa.

Home country preferences are given by:

$$
\begin{aligned}
& \mathrm{U}(\mathrm{c})=\int_{0}^{1} \ln [\mathrm{c}(\mathrm{z})] \mathrm{dz} \quad \theta=0 \\
& \int_{0}^{1} \frac{\mathrm{c}(\mathrm{z})^{\theta}-1}{\theta} \mathrm{dz} \quad \theta \neq 0
\end{aligned}
$$

Households maximize (7) subject to:

$$
\int_{0}^{1} \mathrm{p}(\mathrm{z}) \mathrm{c}(\mathrm{z}) \mathrm{dz}=\mathrm{wL}
$$

$\mathrm{L}$ is the home country's labor force. We assume perfect competition. Stage-1 firms and stage-2 firms maximize profits taking prices as given. The foreign country household and firm maximization problems are similar. We solve the model by substituting the arbitrage relations governing the $\mathrm{z}$ cutoffs into the trade balance equilibrium condition, which we use to solve for the equilibrium relative wage.

As long as $A_{1}\left(z^{\prime}\right) \neq A_{2}\left(z^{\prime}\right)$ for $z^{\prime}=A_{1}^{-1}(\omega)$, where $\omega=w / w^{*}$, then some vertical specialization will occur under free trade. What is VS in our model? Home VS (= foreign country's VS1) is given by:

$$
\int_{z \in \mathbf{F H}} \mathrm{p}_{1}(\mathrm{z})(\mathrm{c}(\mathrm{z})+\mathrm{c} *(\mathrm{z}))\left[\frac{\mathrm{p}(\mathrm{z}) \mathrm{c} *(\mathrm{z})}{\mathrm{p}(\mathrm{z})(\mathrm{c}(\mathrm{z})+\mathrm{c} *(\mathrm{z}))}\right] \mathrm{dz}=\int_{\mathrm{z} \in \mathbf{F} \mathbf{H}} \mathrm{p}_{1}(\mathrm{z}) \mathrm{c} *(\mathrm{z}) \mathrm{dz}
$$

FH is the set of $\mathrm{z}$ in which specialization pattern FH occurs. $\mathrm{p}_{1}(\mathrm{z})=\mathrm{w}^{*} \mathrm{a}_{1} *(\mathrm{z})$ is the price of the stage 1 output, which is produced in the foreign country and imported by the home country (under FH); $\mathrm{p}_{1}(\mathrm{z})\left(\mathrm{c}(\mathrm{z})+\mathrm{c}^{*}(\mathrm{z})\right)$ is the home country's imported inputs. $\mathrm{p}(\mathrm{z})=\mathrm{p}_{1}(\mathrm{z})+\mathrm{wa}_{2}(\mathrm{z})$ is the price of the final good. The fraction in the brackets is exports as a fraction of gross production. The right-hand side shows more clearly that VS is, again, just the import content of exports. Similarly, foreign country VS (= home country's VS1) is given by:

$$
\int_{z \in \mathbf{H F}} \mathrm{p}_{1}(\mathrm{z}) \mathrm{c}(\mathrm{z}) \mathrm{dz}
$$


where, under HF, $\mathrm{p}_{1}(\mathrm{z})=\mathrm{wa}_{1}(\mathrm{z})$. Total vertical specialization exports $(\mathrm{VS}+\mathrm{VS} 1)$ for the home country (as well as the foreign country) is

$$
\int_{z \in \mathbf{H F}} \mathrm{p}_{1}(\mathrm{z}) \mathrm{c}(\mathrm{z}) \mathrm{dz}+\int_{\mathrm{z} \in \mathbf{F H}} \mathrm{p}_{1}(\mathrm{z}) \mathrm{c} *(\mathrm{z}) \mathrm{dz}
$$

We assume that reductions in trade barriers, such as tariffs and transportation costs, are the exogenous shocks driving the growth of vertical specialization and trade. In particular, we implement "iceberg" transportation costs, which can be equivalently modeled as a uniform, proportional tariff levied on all imports, where the tariff revenue finances government purchases that generate no productive or consumption value. ${ }^{33} \mathrm{HF}$, for example, is used to produce good $\mathrm{z}$ (for the home consumer) when:

$$
\begin{aligned}
& \left(1 / \mathrm{g}^{2}\right) \mathrm{wa}_{1}(\mathrm{z})+(1 / \mathrm{g}) \mathrm{w}^{*} \mathrm{a}_{2}(\mathrm{z})<\mathrm{wa}_{1}(\mathrm{z})+\mathrm{wa}_{2}(\mathrm{z}), \\
& \left(1 / \mathrm{g}^{2}\right) \mathrm{wa}_{1}(\mathrm{z})+(1 / \mathrm{g}) \mathrm{w}^{* \mathrm{a}^{*}}{ }_{2}(\mathrm{z})<(1 / \mathrm{g}) \mathrm{w}^{*} \mathrm{a}^{*}{ }_{1}(\mathrm{z})+\mathrm{wa}_{2}(\mathrm{z}), \text { and } \\
& \left(1 / \mathrm{g}^{2}\right) \mathrm{wa}_{1}(\mathrm{z})+(1 / \mathrm{g}) \mathrm{w}^{*} \mathrm{a}^{*}{ }_{2}(\mathrm{z})<(1 / \mathrm{g})\left[\mathrm{w}^{*} \mathrm{a}^{*}{ }_{1}(\mathrm{z})+\mathrm{w}^{*} \mathrm{a}^{*}(\mathrm{z})\right],
\end{aligned}
$$

where 1-g, $\mathrm{g}<1$, represents the fraction of output that is lost in transit or paid as tariffs to the government. Notice that trade barriers eat away at the first stage of production twice - once when the first stage enters the foreign country, and once when the final good is imported back to the home country.

Return to the first special case above. Figure 5 shows that the region of vertical specialization, which under free trade was $\left[\mathrm{z}_{\mathrm{l}}, \mathrm{z}_{\mathrm{h}}\right]$, is now $\left[\mathrm{z}_{\mathrm{lh}}, \mathrm{z}_{\mathrm{hh}}\right]$. By raising the cost of vertical specialization by more than they raise the cost of non-vertical specialization, tariffs and transportation costs create 'wedges' around $\mathrm{A}_{1}(\mathrm{z})$ and $\mathrm{A}_{2}(\mathrm{z})$, and the vertical specialization interval is squeezed on two sides. From the perspective of a home country consumer, the interval $\left[\mathrm{Z}_{\mathrm{l}}, \mathrm{Z}_{\mathrm{h}}\right]$ represents those goods in which production technique HF has been replaced by $\mathrm{HH}$, because the higher tariffs reduce the relative cost of goods produced entirely at home. The interval $\left[\mathrm{Z}_{\mathrm{hh}}, \mathrm{Z}_{\mathrm{h}}\right]$ represents the goods for which HF has been replaced by FF. FF is also subject

\footnotetext{
${ }^{33}$ Lower tariff barriers are commonly thought to be a major force behind the increase in world trade. Rose (1991) and Baier and Bergstrand (1997) are two formal empirical studies that address the causes of the growth of trade. Rose finds that lower tariff barriers are statistically and economically significant in raising trade/GDP shares among small OECD countries. However, Baier and Bergstrand find that tariff reductions contribute to only about $14 \%$ of the post-WW2 increase in bilateral trade.
} 
to a tariff, but not the double effect on stage one that occurs with HF. If tariffs are high enough, the range $\left[\mathrm{z}_{\mathrm{lh}}, \mathrm{z}_{\mathrm{hh}}\right]$ disappears, and vertical specialization does not occur at all. The model then becomes similar to the standard DFS model with tariffs.

We now present a simple numerical application of the second special case to illustrate the effect of tariff liberalization on vertical specialization and trade growth. We assume logarithmic utility and set $\mathrm{L}=\mathrm{L}^{*}$. We specify production technologies in terms of the unit labor requirements for stage one and two production in each country:

$$
\begin{aligned}
& \mathrm{a}_{1}(\mathrm{z})=0.5+\mathrm{z} \quad \mathrm{a}^{*}{ }_{1}(\mathrm{z})=1.75-1.5 \mathrm{z} \\
& \mathrm{a}_{2}(\mathrm{z})=0.5 \quad \mathrm{a}^{*}{ }_{2}(\mathrm{z})=0.25+0.5 \mathrm{z} \quad \mathrm{z} \in[0,1], \mathrm{k} \geq 1
\end{aligned}
$$

Suppose the stages of production cannot be separated, because of prohibitive coordination costs. Then the unit labor requirements are $\mathrm{a}(\mathrm{z})=1+\mathrm{z}$ and $\mathrm{a}^{*}(\mathrm{z})=2-\mathrm{z}$. We think of this case as the "one-stage" case.

We assume tariffs start at $25 \%$ and are reduced to $0 .^{34}$ The top panel of Figure 6 illustrates the implications for vertical specialization and the export share of GDP. The shaded area in the figure shows that vertical specialization (VS+VS1) rises from 0 to $51 \%$ of exports. Repeating the same growth accounting exercise as in Table 4, we find that the increase in VS+VS1 accounts for about 2/3 of the increase in the export share of GDP.

For comparison, results from the one-stage case are also included. They are labeled 'elasticity = 1' (logarithmic utility) and 'elasticity = 7' (where we use the CES utility function). Notice that before vertical specialization occurs, the level and growth rate of exports is roughly similar to the one-stage elasticity $=1$ case. But when tariffs cross the critical threshold (about $17.5 \%$ ) at which vertical specialization occurs, the export shares rise much more sharply in our model. For example, when tariffs fall from $17.5 \%$ to 0 , the export share of GDP rises from 0.25 to 0.97. By contrast, in the one-stage model, the upper bound on the export share of GDP is 0.5. All together, the growth in the export share of GDP owing to the 25 percentage point tariff

\footnotetext{
${ }^{34}$ Since the late 1950 s manufactured tariffs have fallen by roughly 15 percentage points and Baier and Bergstrand (1997) report that transportation costs, as measured by CIF/FOB ratios, fell by about 4 percentage points between 1958-60 and 1986-88. See Hummels (1998a, 1998b) for a careful examination of trends in transportation costs. In addition, non-tariff barriers have likely dropped. For these reasons we simulate a 25 percentage point decline in tariffs. Yi (1999), which is also a revision and extension of IY (1997), calibrates and simulates a dynamic general
} 
reduction is more than twice as large as that implied by the one-stage elasticity $=1$ case. In the one-stage model, an elasticity of substitution of 7 is needed to generate the same amount of export share growth rate as in the vertical specialization case. ${ }^{35}$

There are two propagation mechanisms behind the greater trade growth. First, the presence of vertical specialization magnifies the tariff reduction, leading to greater trade growth. Second, much of the growth in exports involves goods that embody imported inputs or foreign value-added, i.e., VS goods. Hence, export shares of GDP can rise to higher levels than is the case when exports embody only domestic value-added.

This exercise is consistent with case study evidence linking tariff liberalization to vertical specialization and trade growth. IY (1997) and HRY (1998) report that the 1965 U.S.-Canada Auto Pact reduced tariffs from approximately 10\%-20\% to zero on automotive trade between these countries. Within four years bilateral trade had quintupled, rising from less than $\$ 1$ billion to over $\$ 5$ billion, and within six years, the amount of vertical specialization trade had increased from zero to about $20 \%$ of total auto trade. The case study of Opel España shows similar effects around the time when Spain joined the European Union.

The bottom panel of Figure 6 illustrates the gains from trade for the vertical specialization case, as well as for the one-stage case. For each tariff rate, it plots the welfare gains from a 2.5 percentage point reduction in the tariff rate. Welfare is measured in terms of the percentage increase in the autarky-level consumption of all goods that would be needed to raise utility under tariff rate $\tau$ to the utility under tariff rate $\tau-.025$. The figure shows that the welfare gains for each tariff reduction increases after vertical specialization kicks in. For example, when tariffs fall from $7.5 \%$ to $5 \%$, the welfare gain in the vertical specialization model is equivalent to 2.3 percent of autarky consumption, while the welfare gain from the one-stage elasticity $=1$

equilibrium trade model to see whether vertical specialization is a quantitatively significant propagation mechanism helping to explain the growth of trade.

${ }^{35}$ Suppose, in our model that there are prohibitive tariffs/transportation costs on final goods trade only, so that only first-stage intermediate goods can be traded. Then our model is analogous to the Sanyal/Jones framework. We simulated a tariff reduction and found trade growth and gains from trade are similar to that of the standard one-stage framework. This case shows that the ability to trade both stages, i.e., engage in vertical specialization, and not the mere existence of multi-stage production, is key to high trade growth and the gains from trade in our model. Additionally, the ability to trade both stages may be critical not just to vertical specialization, but to any specialization. Suppose the production technology is given by the example in the bottom panel of Figure 5, but where the equilibrium wage under free trade falls exactly at the intersection of $A_{1}(z)$ and $A_{2}(z)$. In this instance, any specialization requires trade in both stages - prohibitive trade barriers on just the first stage would return this world to autarky. 
(elasticity=7) case is equivalent to only 1.4 (1.2) percent of autarky consumption. Summarizing, our numerical exercise shows that vertical specialization leads to the type of trade growth that can only be generated with high elasticities in single-stage models, and that the gains from trade barrier reduction are potentially much larger when vertical specialization occurs.

We close this section with two additional points. Our model of vertical specialization illustrates the effect of country size on the pattern of specialization and trade. In one-stage trade models with complete specialization (such as the DFS model) small countries trade a greater share of output than large countries. Assuming identical preferences, each country imports its world income share of each good, implying that the export share of output is one minus the country's world income share. Our model extends this logic beyond goods to stages. Our simulations show that specialization in stages leads small countries to trade a larger share of output and to vertically trade a larger share of total trade. That is country size affects both the extent and composition of trade. This provides an explanation for the small VS share of the U.S., Japan, and Germany, and the much larger VS shares for countries like Canada, Belgium, and the Netherlands. It also helps explain why smaller countries have large shares of exports to GDP, possibly exceeding 1 . This can happen as long as a significant portion of exports consists of imported inputs (foreign value-added).

Finally, vertical specialization increases the range of goods that a country has some part of producing. In the top panel of Figure 4, the home country is producing some or all of $\mathrm{z} \in$ $\left[0, \mathrm{z}_{\mathrm{h}}\right]$ and the foreign country is producing some or all $\mathrm{z} \in\left[\mathrm{z}_{1}, 1\right]$. Absent vertical specialization, the range would be $\left[0, z_{l h}\right]$ for the home country and $\left[z_{l h}, 1\right]$ for the foreign country where $z_{l}<z_{l h}<$ $\mathrm{z}_{\mathrm{h}}$. An examination of the data from our input-output tables indicates that all countries are producing in virtually every sector. While this seems to suggest that countries specialize little, the model provides a sensible alternative explanation. Countries specialize in stages, not in sectors, and industrial statistics that focus on sectors miss this specialization.

\section{CONCLUSION}

Much attention has been focused on the extent of international integration as measured by growing trade shares of output. In this paper, we identify and document a deeper dimension to 
international integration involving the interconnection of production processes in a vertical trading chain that stretches across many countries. Our contributions are two-fold.

First, we develop a particular verticality concept that we call vertical specialization, and then we measure it using input-output tables. Our primary measure, VS, is the imported input content of (or foreign value-added embodied in) exports. Our evidence indicates that, as of 1990, VS accounts for 20 percent of merchandise exports in the OECD database countries. Smaller countries, and those outside the OECD database (Ireland, Korea, Taiwan, Mexico) have VS shares as high as 40 percent of exports. When we augment our primary measure to include imported investment goods, as well as exports of intermediates that are used to produce other countries' export goods, vertical specialization accounts for 30 percent of OECD and world exports. We estimate that the world VS share has grown about 40 percent in the last twenty-five years.

Decompositions reveal that the sectors where most export growth has taken place (chemicals and machinery) are also the sectors where most VS growth has occurred. Also, reliance on imported inputs has grown faster for exported goods than for domestically consumed goods. Finally, vertical specialization in the OECD primarily involves other OECD countries inputs from developed nations are transformed and exported to other developed nations. A notable exception to this pattern is the US, which has become more oriented toward developing countries at the same time that vertical specialization has grown rapidly.

Our second contribution is a simple model of multi-stage production that provides insights into why vertical specialization has grown, and how it is connected to the growth of trade and the gains from trade. The model embeds two key ideas. First, the ability to separate stages of production allows a finer division of specialization according to comparative advantage. Second, trade barriers are incurred repeatedly as the good-in-process crosses multiple borders. The consequence is that even small reductions in trade barriers can provide strong incentives to vertically specialize. Trade grows, and the vertical component of that trade grows even more. We show that, for any given trade barrier reduction, trade and the gains from trade will be greater with vertical specialization.

We conclude by identifying three issues for future research. Foreign direct investment has increased even more rapidly than trade. On the other hand, the share of U.S. multinationals 
trade in total U.S. trade has declined since 1977. What is the relation between growth in multinational activity and the growth in vertical specialization? Do the growth of and gains from vertical specialization depend as much on investment liberalization as it does on trade liberalization $?^{36}$

Second, anecdotal and case study evidence suggests that vertical specialization may be large within regional trading blocs. Is this because of tariff preferences, corollary investment liberalization, geographic proximity that minimizes freight charges and shipping time, or some combination of the three? Note that Mexican maquiladoras resulted from changes in trade laws specifically designed to enhance vertical specialization. (Imported inputs from the U.S. are not subject to Mexican tariffs as long as they are used in the maquiladoras, and only the Mexican value-added is subject to U.S. tariffs when maquiladora goods are exported back to the U.S.). As vertical specialization tends to magnify the effects of barriers, it may also magnify the welfare consequences, malignant or benign, of preferential barriers. ${ }^{37}$

Finally, the changing nature of trade may tell us something interesting about the changing nature of trade barriers. In our model, the costs of separating the first and second stages of production are represented by the ad-valorem tariff or "iceberg" transportation cost. However, as the sequential production nature of vertical specialization requires intensive oversight and coordination of production, representing the costs of separating stages of production as coordination or information costs may be important, as well. Improvements in communications technologies (faxes, email, videoconferencing) and dramatic declines in the costs of information transmission have made it easier for firms to coordinate and monitor production in diverse locations. This suggests an investigation into the relative importance of the costs of moving information and the costs of moving goods (tariffs, transportation) in explaining the growth of vertical specialization.

\footnotetext{
${ }^{36}$ The idea that trade liberalization and investment liberalization are complementary has recently been modeled in the theoretical literature (see, for example, Markusen [1997]).

${ }^{37}$ Two of the case studies in IY (1997) and HRY (1998), U.S.-Mexico maquiladora trade and the 1965 U.S.-Canada Auto Pact, are results of preferential tariff reductions. As noted earlier, these reductions led to rapid growth in vertical specialization. Recently, there has been much research on regional trade agreements versus multilateral trade agreements. See, for example, Krugman (1992), Grossman and Helpman (1995), and Freund (1998).
} 
FIGURE 1

Vertical Specialization

Country 1

Intermediate goods

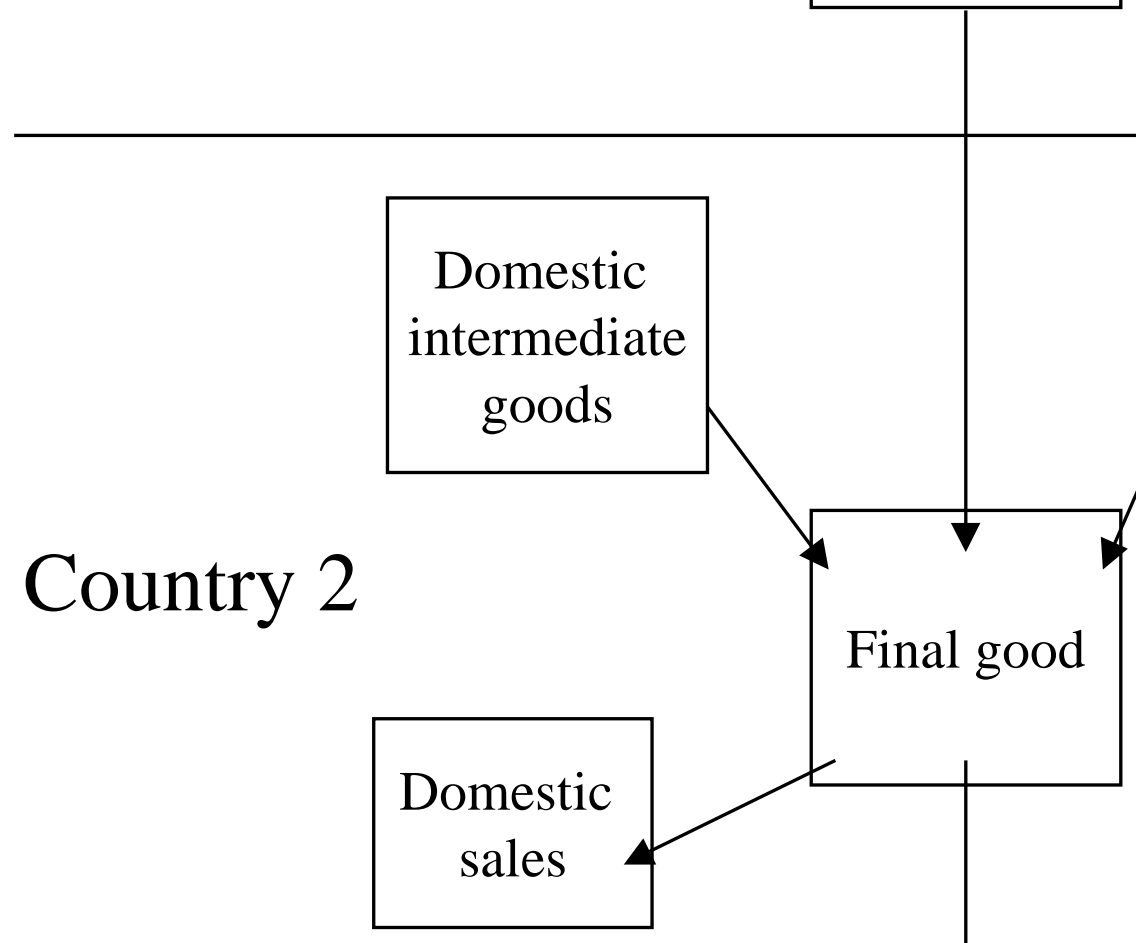

Country 3

Capital and labor 
FIGURE 2

United States Vertical Specialization and Intermediate Trade
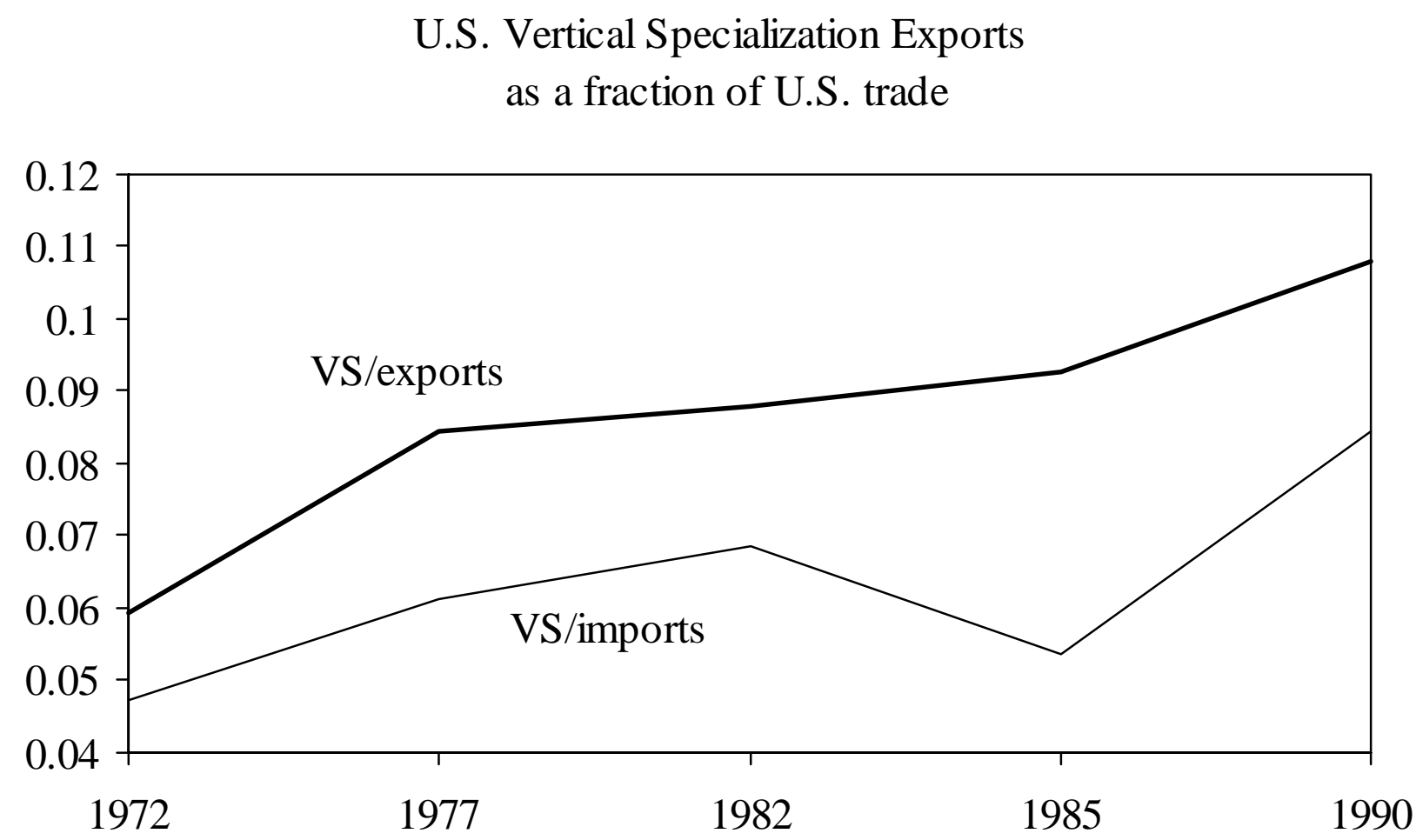

U.S. Intermediate Trade as a fraction of U.S. trade

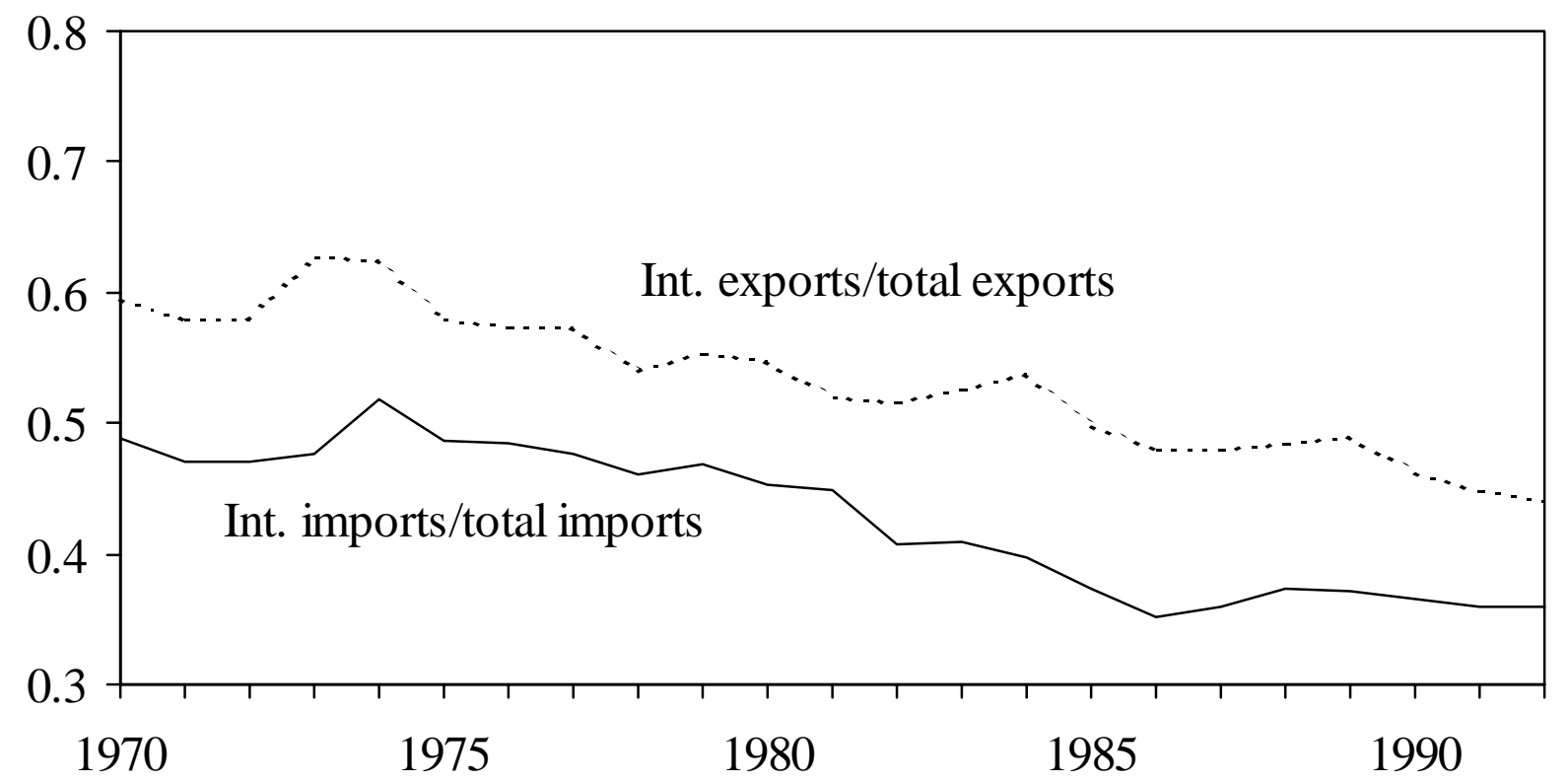

Sources: Top panel: OECD Input-Output Database; Authors' calculations. Bottom panel: Statistics Canada World Trade Database; see Appendix I. 
FIGURE 3

Mexican Exports and Vertical Specialization

VS Exports as a Share of Total Exports and Exports as a Share of GDP

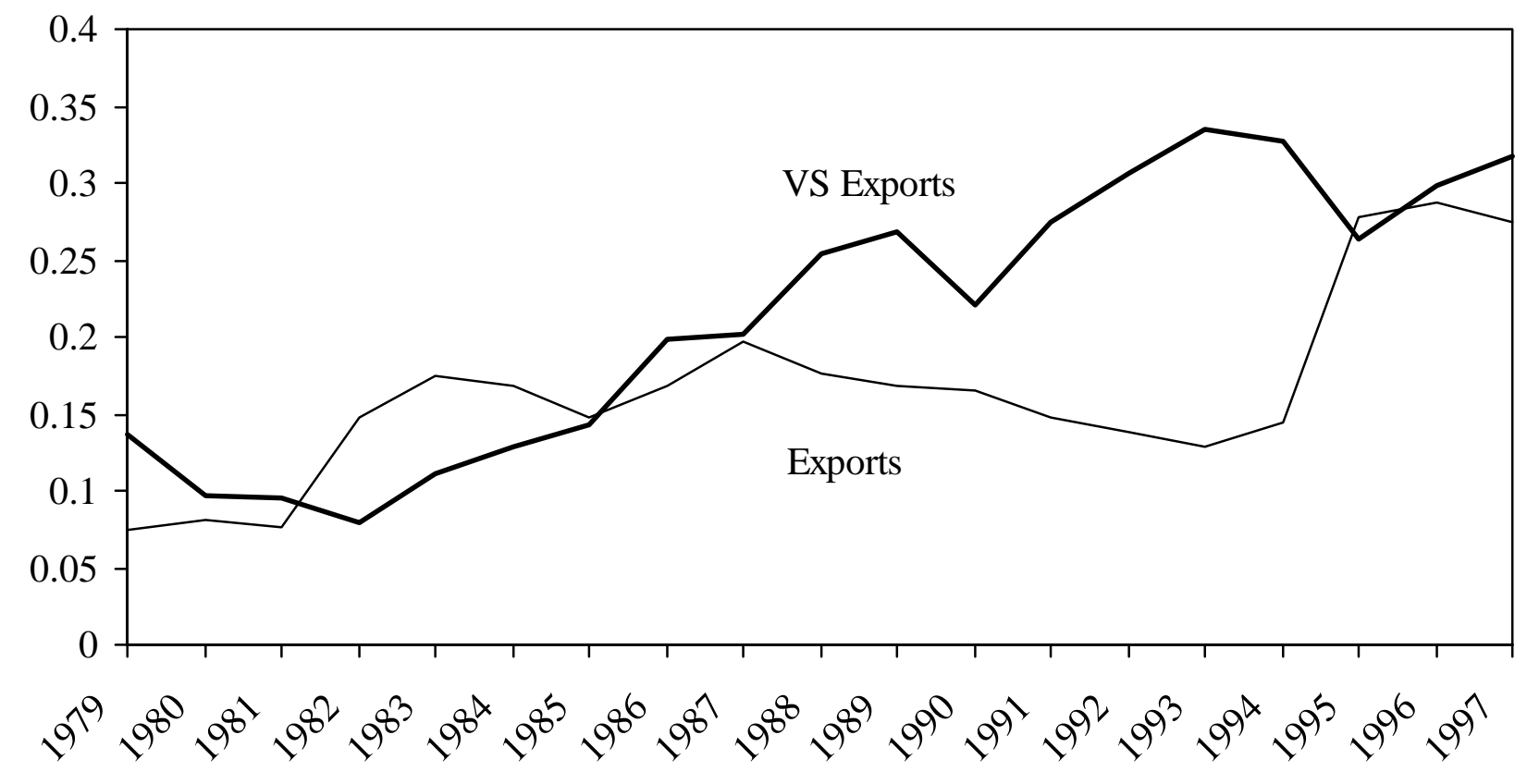

Note: Calculations include maquiladora activity only.

Sources: Banco de Mexico, INEGI (See Appendix I). 


\section{FIGURE 4}

\section{Vertical Specialization Model}

Free Trade
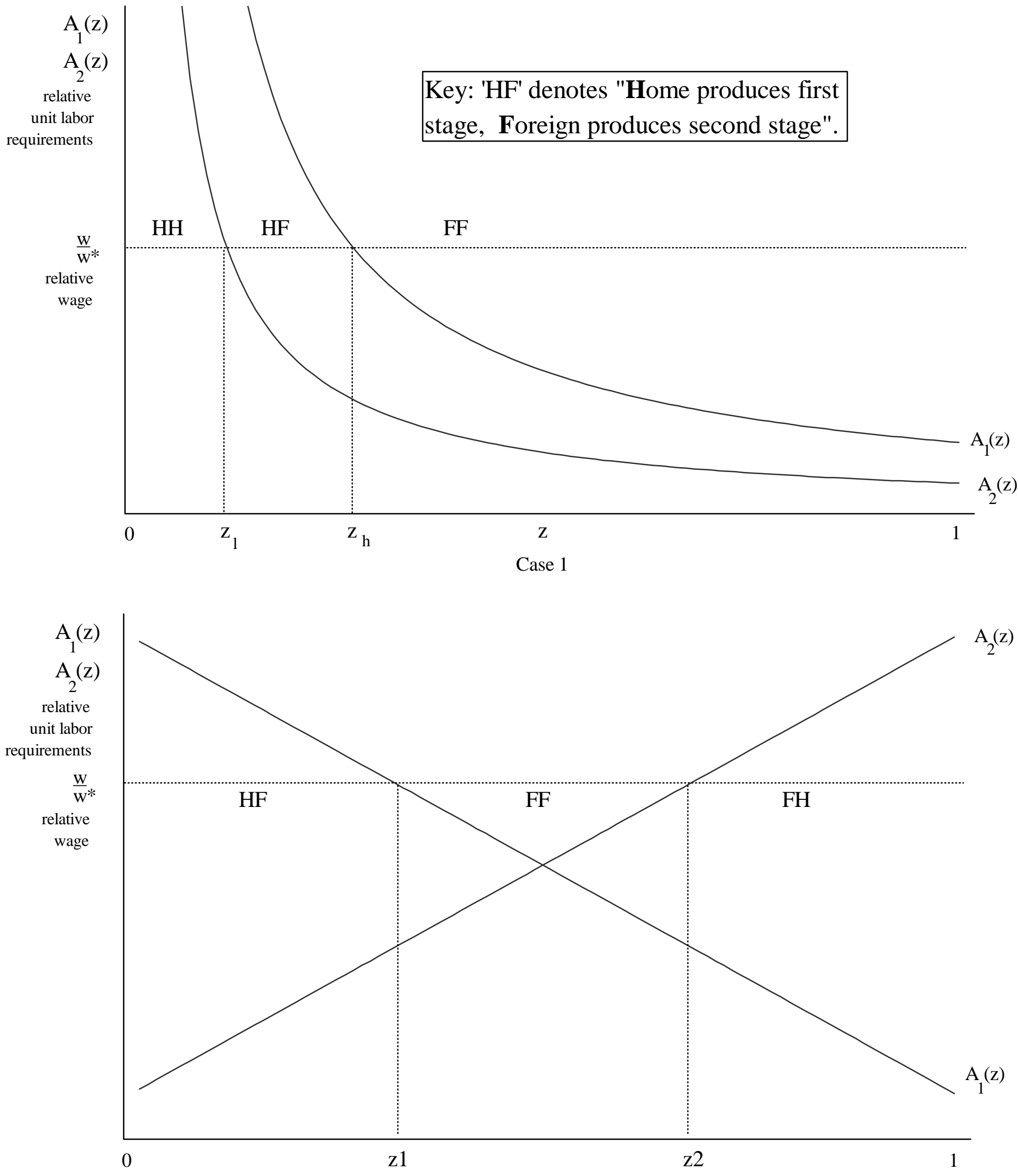

Case 2 


\section{FIGURE 5}

Vertical Specialization Model

Tariffs/Transportation Costs (Home Consumer's Perspective)

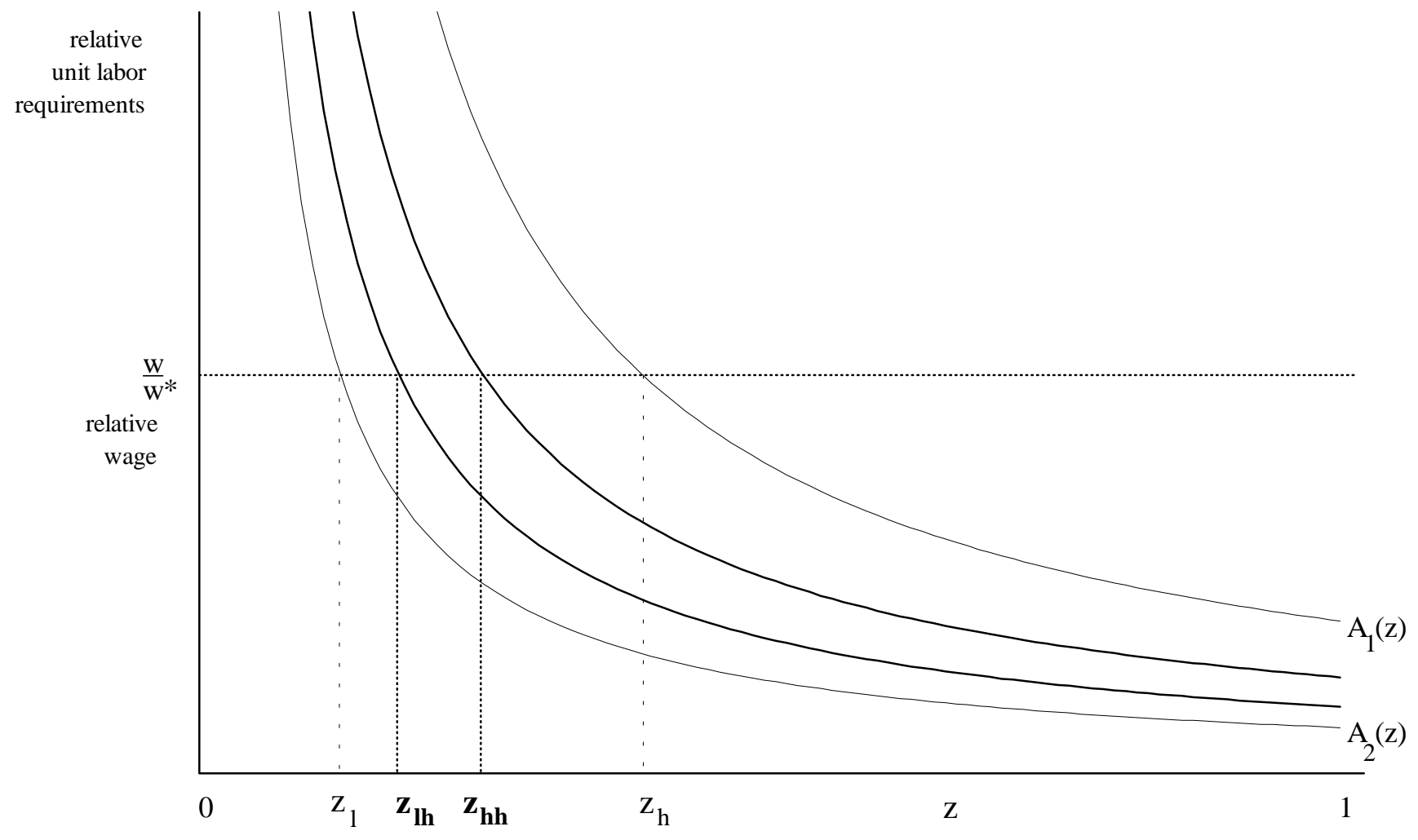

Range of goods

$$
\begin{aligned}
& {\left[0, \mathrm{z}_{\mathrm{lh}}\right]} \\
& {\left[\mathrm{z}_{\mathrm{lh}}, \mathrm{z}_{\mathrm{hh}}\right]}
\end{aligned}
$$$$
\left[\mathrm{Z}_{\mathrm{hh}}, 1\right]
$$

Production Technology

$\mathrm{HH}$

$\mathrm{HF}$

$\mathrm{FF}$ 
FIGURE 6

Vertical Specialization Model

Export Share of GDP as a Function of Tariff Rates

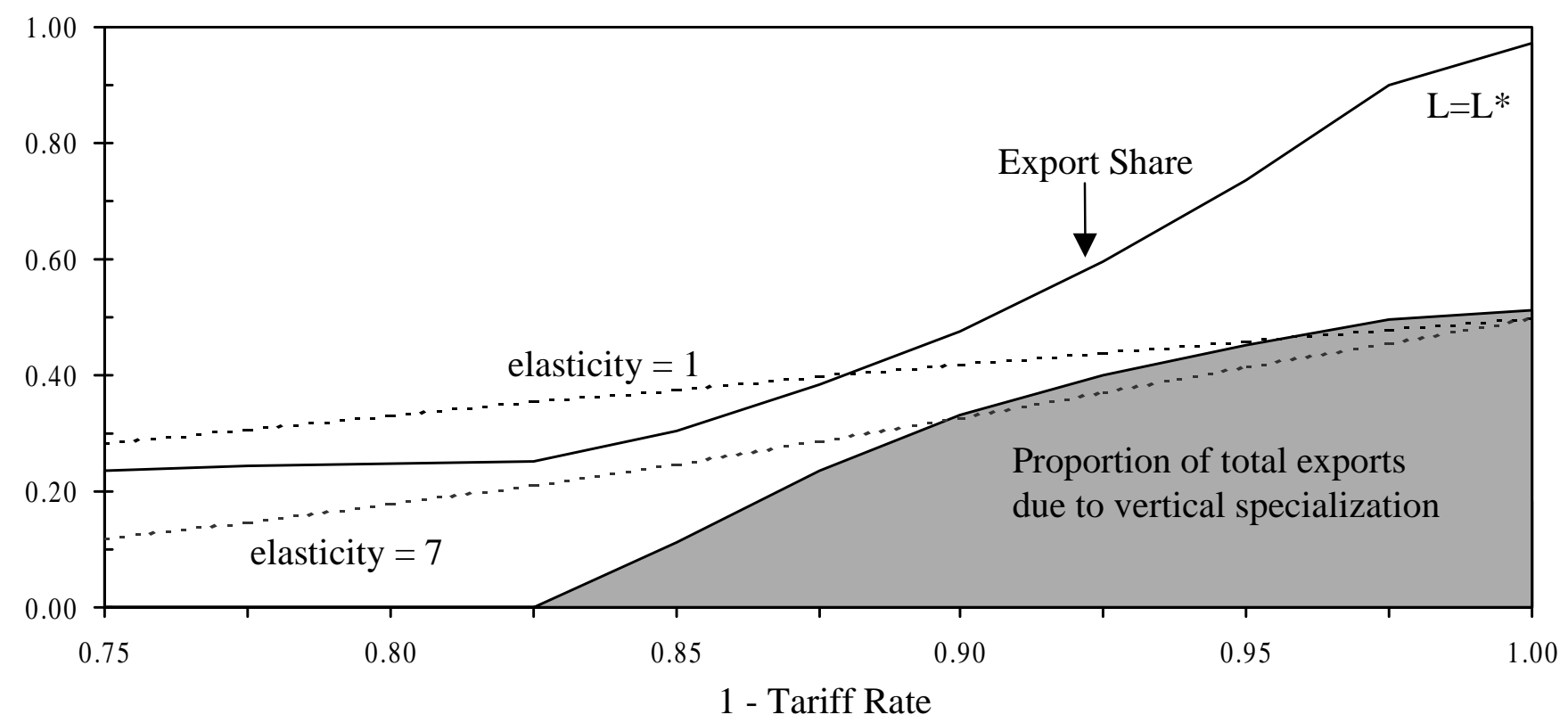

Gains from Trade (Home Country)

Marginal Gains from 2.5 Percentage Point Tariff Reduction

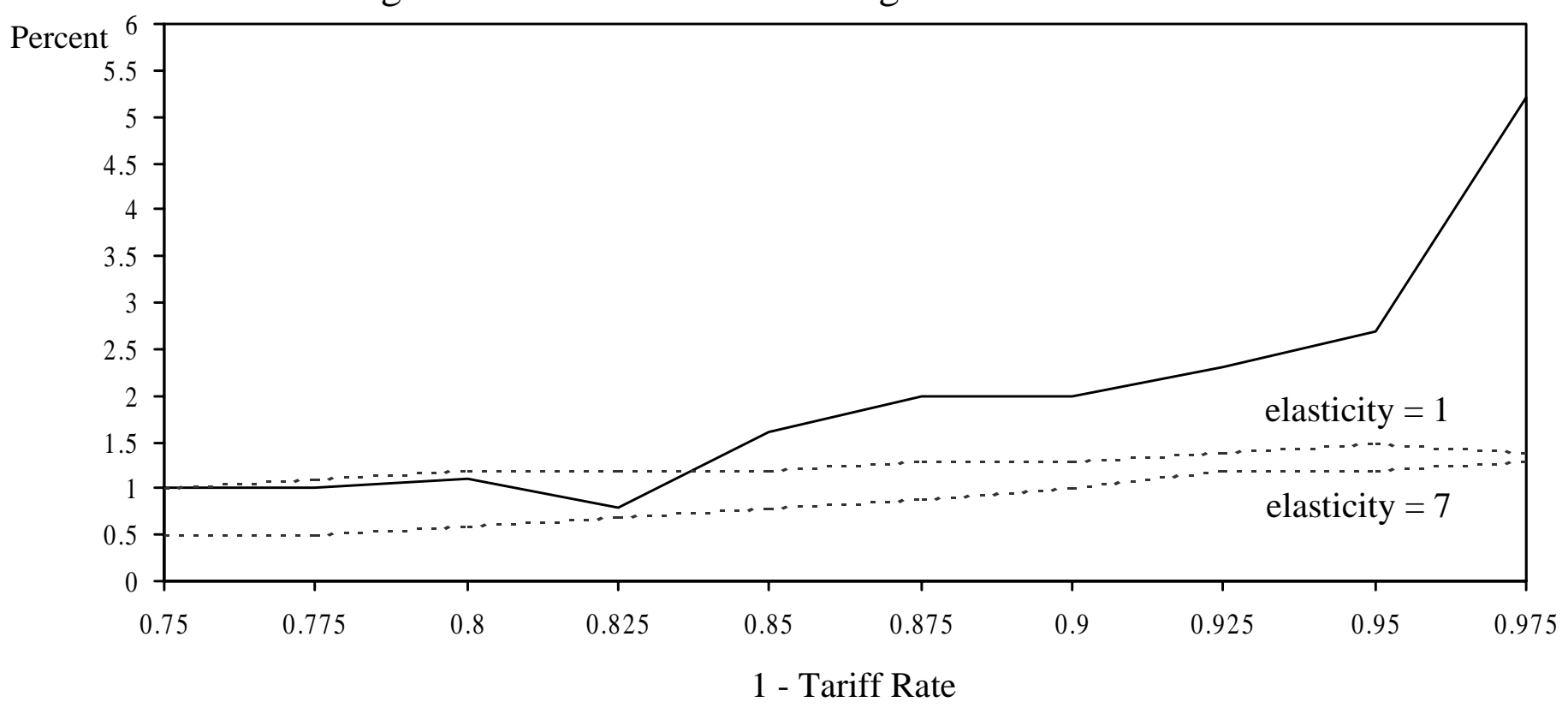

Note: Gains measured relative to autarky-level consumption. 


\section{TABLE 1}

VS EXPORTS AS A SHARE OF MERCHANDISE EXPORTS: OECD DATABASE, SUMMARY RESULTS

\begin{tabular}{|c|c|c|c|c|c|c|c|c|c|c|}
\hline INITIAL YEAR & $\begin{array}{c}\text { Australia } \\
1968 \\
\end{array}$ & $\begin{array}{c}\text { Canada } \\
1971 \\
\end{array}$ & $\begin{array}{c}\text { Denmark } \\
1972 \\
\end{array}$ & $\begin{array}{c}\text { France } \\
1972 \\
\end{array}$ & $\begin{array}{c}\text { Germany } \\
1978 \\
\end{array}$ & & $\begin{array}{c}\text { Japan } \\
1970 \\
\end{array}$ & $\begin{array}{l}\text { Netherlands } \\
1972 \\
\end{array}$ & $\begin{array}{c}\text { United } \\
\text { Kingdom } \\
1968 \\
\end{array}$ & $\begin{array}{c}\text { United } \\
\text { States } \\
1972 \\
\end{array}$ \\
\hline OVERALL & 0.09 & 0.20 & 0.29 & 0.18 & 0.18 & & 0.13 & 0.34 & 0.20 & 0.06 \\
\hline CHEMICALS & 0.17 & 0.17 & 0.35 & 0.21 & 0.24 & & 0.12 & 0.30 & 0.23 & 0.05 \\
\hline MACHINERY & 0.19 & 0.37 & 0.31 & 0.18 & 0.15 & & 0.10 & 0.36 & 0.15 & 0.06 \\
\hline OTHER & 0.08 & 0.11 & 0.27 & 0.17 & 0.22 & & 0.18 & 0.33 & 0.25 & 0.06 \\
\hline FINAL YEAR & $\begin{array}{c}\text { Australia } \\
1989 \\
\end{array}$ & $\begin{array}{c}\text { Canada } \\
1990 \\
\end{array}$ & $\begin{array}{c}\text { Denmark } \\
1990 \\
\end{array}$ & $\begin{array}{c}\text { France } \\
1990 \\
\end{array}$ & $\begin{array}{c}\text { Germany } \\
1990 \\
\end{array}$ & $\begin{array}{l}\text { Italy } \\
1985 \\
\end{array}$ & $\begin{array}{c}\text { Japan } \\
1990 \\
\end{array}$ & $\begin{array}{l}\text { Netherlands } \\
1986 \\
\end{array}$ & $\begin{array}{c}\text { United } \\
\text { Kingdom } \\
1990 \\
\end{array}$ & $\begin{array}{c}\text { United } \\
\text { States } \\
1990 \\
\end{array}$ \\
\hline OVERALL & 0.11 & 0.27 & 0.29 & 0.24 & 0.20 & 0.27 & 0.11 & 0.37 & 0.26 & 0.11 \\
\hline CHEMICALS & 0.21 & 0.21 & 0.33 & 0.27 & 0.24 & 0.33 & 0.18 & 0.42 & 0.26 & 0.09 \\
\hline MACHINERY & 0.23 & 0.44 & 0.33 & 0.25 & 0.17 & 0.24 & 0.09 & 0.42 & 0.29 & 0.12 \\
\hline OTHER & 0.10 & 0.15 & 0.27 & 0.22 & 0.22 & 0.28 & 0.16 & 0.34 & 0.22 & 0.10 \\
\hline $\begin{array}{l}\text { Growth of Overall VS Share of Exports } \\
\text { First Year to Last Year, \% }\end{array}$ & $24.8 \%$ & $35.2 \%$ & $2.2 \%$ & $34.0 \%$ & $6.3 \%$ & & $-18.2 \%$ & $9.8 \%$ & $27.8 \%$ & $81.9 \%$ \\
\hline
\end{tabular}

Source: Authors' calculations based on OECD Input-Output Database. 
TABLE 2

VS EXPORTS AS A SHARE OF MERCHANDISE EXPORTS: OECD DATABASE; SECTORAL RESULTS

\begin{tabular}{|c|c|c|c|c|c|c|c|c|c|c|c|c|c|c|c|c|c|c|c|}
\hline & \multicolumn{2}{|c|}{ Australia } & \multicolumn{2}{|c|}{ Canada } & \multicolumn{2}{|c|}{ Denmark } & \multicolumn{2}{|c|}{ France } & \multicolumn{2}{|c|}{ Germany } & \multirow{2}{*}{$\begin{array}{l}\text { Italy } \\
1985\end{array}$} & \multicolumn{2}{|c|}{ Japan } & \multicolumn{2}{|c|}{ Netherlands } & \multicolumn{2}{|c|}{$\begin{array}{c}\text { United } \\
\text { Kingdom }\end{array}$} & \multicolumn{2}{|c|}{$\begin{array}{l}\text { United } \\
\text { States }\end{array}$} \\
\hline & 1968 & 1989 & 1971 & 1990 & 1972 & 1990 & 1972 & 1990 & 1978 & 1990 & & 1970 & 1990 & 1972 & 1986 & 1968 & 1990 & 1972 & 1990 \\
\hline OVERALL & 0.09 & 0.11 & 0.20 & 0.27 & 0.29 & 0.29 & 0.18 & 0.24 & 0.18 & 0.20 & 0.27 & $\mathbf{0 . 1 3}$ & 0.11 & 0.34 & 0.37 & 0.20 & 0.26 & 0.06 & 0.11 \\
\hline \multicolumn{20}{|l|}{ CHEMICALS } \\
\hline Industrial chemicals & 0.18 & 0.22 & 0.17 & 0.21 & 0.39 & 0.39 & 0.21 & 0.28 & 0.24 & 0.24 & 0.34 & 0.13 & 0.19 & 0.30 & 0.42 & 0.24 & 0.28 & 0.05 & 0.10 \\
\hline Drugs \& medicines & 0.11 & 0.17 & 0.13 & 0.12 & 0.26 & 0.25 & 0.19 & 0.25 & 0.00 & 0.00 & 0.24 & 0.07 & 0.08 & 0.29 & 0.33 & 0.14 & 0.16 & 0.03 & 0.05 \\
\hline \multicolumn{20}{|l|}{ MACHINERY } \\
\hline Non-electrical machinery & 0.12 & 0.20 & 0.20 & 0.25 & 0.28 & 0.31 & 0.19 & 0.22 & 0.14 & 0.14 & 0.23 & 0.10 & 0.09 & 0.32 & 0.34 & 0.14 & 0.24 & 0.05 & 0.09 \\
\hline Office \& computing machinery & 0.00 & 0.00 & 0.37 & 0.52 & 0.00 & 0.00 & 0.23 & 0.32 & 0.15 & 0.19 & 0.36 & 0.10 & 0.10 & 0.37 & 0.44 & 0.11 & 0.37 & 0.05 & 0.18 \\
\hline Electrical apparatus, n.e.c. & 0.13 & 0.20 & 0.17 & 0.22 & 0.29 & 0.32 & 0.17 & 0.21 & 0.14 & 0.15 & 0.22 & 0.14 & 0.12 & 0.37 & 0.42 & 0.19 & 0.26 & 0.06 & 0.10 \\
\hline Radio, TV \& Comm. Equip. & 0.20 & 0.32 & 0.21 & 0.41 & 0.33 & 0.36 & 0.14 & 0.18 & 0.00 & 0.00 & 0.25 & 0.09 & 0.09 & 0.00 & 0.00 & 0.16 & 0.29 & 0.05 & 0.13 \\
\hline Shipbuilding \& repairing & 0.09 & 0.19 & 0.16 & 0.33 & 0.36 & 0.38 & 0.17 & 0.27 & 0.17 & 0.21 & 0.23 & 0.09 & 0.09 & 0.35 & 0.34 & 0.11 & 0.22 & 0.06 & 0.08 \\
\hline Other transport & 0.10 & 0.12 & 0.24 & 0.29 & 0.51 & 0.39 & 0.09 & 0.11 & 0.00 & 0.00 & 0.16 & 0.09 & 0.09 & 0.32 & 0.47 & 0.13 & 0.28 & 0.08 & 0.12 \\
\hline Motor vehicles & 0.27 & 0.27 & 0.44 & 0.51 & 0.00 & 0.00 & 0.18 & 0.25 & 0.16 & 0.20 & 0.25 & 0.09 & 0.09 & 0.43 & 0.51 & 0.16 & 0.32 & 0.08 & 0.17 \\
\hline Aircraft & 0.26 & 0.16 & 0.23 & 0.25 & 0.00 & 0.00 & 0.22 & 0.35 & 0.18 & 0.22 & 0.27 & 0.25 & 0.31 & 0.48 & 0.59 & 0.13 & 0.32 & 0.05 & 0.09 \\
\hline Professional goods & 0.22 & 0.21 & 0.16 & 0.26 & 0.25 & 0.28 & 0.14 & 0.15 & 0.12 & 0.14 & 0.21 & 0.09 & 0.08 & 0.28 & 0.30 & 0.13 & 0.23 & 0.05 & 0.08 \\
\hline \multicolumn{20}{|l|}{ OTHER } \\
\hline Agriculture, forestry \& fishing & 0.06 & 0.07 & 0.07 & 0.11 & 0.17 & 0.20 & 0.06 & 0.13 & 0.15 & 0.16 & 0.13 & 0.05 & 0.06 & 0.14 & 0.16 & 0.16 & 0.14 & 0.04 & 0.06 \\
\hline Mining \& quarrying & 0.06 & 0.09 & 0.06 & 0.07 & 0.21 & 0.07 & 0.21 & 0.23 & 0.10 & 0.14 & 0.04 & 0.07 & 0.07 & 0.03 & 0.06 & 0.07 & 0.13 & 0.02 & 0.05 \\
\hline Food, beverages \& tobacco & 0.08 & 0.08 & 0.10 & 0.13 & 0.22 & 0.24 & 0.11 & 0.16 & 0.22 & 0.21 & 0.22 & 0.15 & 0.12 & 0.28 & 0.32 & 0.28 & 0.19 & 0.06 & 0.07 \\
\hline Textiles, apparel \& leather & 0.21 & 0.23 & 0.23 & 0.26 & 0.42 & 0.39 & 0.20 & 0.26 & 0.24 & 0.25 & 0.25 & 0.15 & 0.15 & 0.45 & 0.53 & 0.24 & 0.32 & 0.07 & 0.12 \\
\hline Wood products \& furniture & 0.14 & 0.16 & 0.10 & 0.13 & 0.31 & 0.31 & 0.15 & 0.18 & 0.17 & 0.17 & 0.19 & 0.24 & 0.18 & 0.31 & 0.39 & 0.33 & 0.27 & 0.06 & 0.07 \\
\hline Paper, paper products \& printing & 0.18 & 0.18 & 0.09 & 0.12 & 0.24 & 0.28 & 0.13 & 0.20 & 0.19 & 0.24 & 0.22 & 0.09 & 0.09 & 0.23 & 0.28 & 0.21 & 0.23 & 0.06 & 0.08 \\
\hline Petroleum \& coal products & 0.57 & 0.22 & 0.38 & 0.37 & 0.77 & 0.53 & 0.34 & 0.37 & 0.47 & 0.44 & 0.58 & 0.42 & 0.51 & 0.64 & 0.63 & 0.52 & 0.16 & 0.10 & 0.27 \\
\hline Rubber \& plastic products & 0.19 & 0.20 & 0.19 & 0.23 & 0.36 & 0.38 & 0.23 & 0.33 & 0.19 & 0.21 & 0.33 & 0.11 & 0.11 & 0.37 & 0.41 & 0.20 & 0.29 & 0.05 & 0.09 \\
\hline Non-metallic mineral products & 0.10 & 0.11 & 0.10 & 0.13 & 0.19 & 0.23 & 0.08 & 0.11 & 0.14 & 0.14 & 0.19 & 0.11 & 0.09 & 0.17 & 0.21 & 0.15 & 0.18 & 0.04 & 0.06 \\
\hline Iron \& steel & 0.09 & 0.15 & 0.17 & 0.22 & 0.26 & 0.31 & 0.24 & 0.25 & 0.25 & 0.20 & 0.36 & 0.22 & 0.17 & 0.34 & 0.29 & 0.21 & 0.25 & 0.10 & 0.09 \\
\hline Non-ferrous metals & 0.06 & 0.10 & 0.16 & 0.24 & 0.44 & 0.44 & 0.43 & 0.45 & 0.40 & 0.39 & 0.49 & 0.38 & 0.43 & 0.00 & 0.00 & 0.44 & 0.33 & 0.18 & 0.15 \\
\hline Metal products & 0.09 & 0.15 & 0.15 & 0.21 & 0.33 & 0.33 & 0.16 & 0.19 & 0.17 & 0.16 & 0.20 & 0.11 & 0.10 & 0.29 & 0.32 & 0.18 & 0.24 & 0.07 & 0.09 \\
\hline Other manufacturing & 0.14 & 0.18 & 0.17 & 0.25 & 0.27 & 0.26 & 0.15 & 0.16 & 0.17 & 0.18 & 0.34 & 0.11 & 0.09 & 0.41 & 0.32 & 0.18 & 0.26 & 0.10 & 0.10 \\
\hline
\end{tabular}

Source: Authors' calculations based on OECD Input-Output Database. 
TABLE 3

VS EXPORTS: IRELAND, KOREA, TAIWAN

\begin{tabular}{|c|c|c|c|c|c|}
\hline \multirow[b]{2}{*}{ Ireland } & $\underline{1964}$ & $\underline{1975}$ & & $\underline{1990}$ & \\
\hline & 0.287 & 0.348 & & 0.278 & \\
\hline \multirow{3}{*}{ Korea } & $\underline{1963}$ & $\underline{1970}$ & & $\underline{1990}$ & $\underline{1993}$ \\
\hline & $\overline{0.259}$ & $\overline{0.320}$ & & $\overline{0.334}$ & $\overline{0.301}$ \\
\hline & & & $\underline{1981}$ & & $\underline{1994}$ \\
\hline Taiwan & & & $\overline{0.376}$ & & $\overline{0.405}$ \\
\hline
\end{tabular}

Sources: Central Statistics Office (Ireland), Bank of Korea Input-Output Table, Taiwan Central Bank. Note: VS is based on (3). All numbers are expressed as a share of total merchandise exports.

\section{TABLE 4}

CONTRIBUTION OF VS EXPORTS TO GROWTH IN (MERCHANDISE) EXPORT SHARE OF (MERCHANDISE) GROSS OUTPUT FROM FIRST TO LAST YEAR OF SAMPLE

\begin{tabular}{lccc} 
Country & First, Last Year & $\begin{array}{c}\text { Increase in Export Share } \\
\text { of Gross Output }\end{array}$ & $\begin{array}{c}\text { Contribution of } \\
\text { VS Share (percent) }\end{array}$ \\
\cline { 2 - 2 } & 1968,1989 & 0.06 & $\mathbf{1 6 . 2}$ \\
Canada & 1971,1990 & 0.08 & $\mathbf{5 0 . 9}$ \\
Denmark & 1972,1990 & 0.17 & $\mathbf{3 0 . 8}$ \\
France & 1972,1990 & 0.11 & $\mathbf{3 2 . 4}$ \\
Germany & 1978,1990 & 0.09 & $\mathbf{2 2 . 2}$ \\
Japan & 1970,1990 & 0.03 & $\mathbf{6 . 1}$ \\
Netherlands & 1972,1986 & 0.10 & $\mathbf{4 8 . 2}$ \\
United Kingdom & 1968,1990 & 0.15 & $\mathbf{3 1 . 7}$ \\
United States & 1972,1990 & 0.07 & $\mathbf{1 4 . 1}$ \\
& & & Contribution of \\
& & & $\underline{\text { VS Share (percent) }}$ \\
Country & First, Last Year & Increase in Export Share & $\mathbf{3 3 . 5}$ \\
Ireland & 1964,1990 & of Gross Output & $\mathbf{3 0 . 7}$ \\
Korea & 1963,1993 & 0.27 & $\mathbf{3 4 . 6}$ \\
Korea & 1963,1990 & 0.17 & $\mathbf{4 0 . 0}$ \\
Mexico* & 1979,1997 & 0.16 & $\mathbf{5 3 . 4}$ \\
Mexico* & 1979,1994 & 0.19 & $\mathbf{4 9 . 0}$ \\
Taiwan & 1981,1994 & 0.08 & $\mathbf{5 1 . 8}$ \\
Taiwan* & 1961,1994 & 0.09 &
\end{tabular}

* GDP used in place of Gross Output.

Source: Authors' calculations based on OECD Input-Output Database.

Ireland Central Statistical Office; Bank of Korea; INEGI, Mexico;

Quarterly National Income Satistics in Taiwan Area, The Republic of China;

Directorate-General of Budget, Accounting and Statistics, Executive Yuan, Taiwan;

UNCTAD, Handbook of International Trade and Development Statistics, 1995;

Chenery, Robinson, Syrquin (1987) 


\begin{tabular}{lcccccc}
\multicolumn{1}{c}{ Set of Countries: } & \multicolumn{2}{c}{1} & & & \\
\cline { 2 - 3 } & $\begin{array}{c}\text { Countries' } \\
\text { Share of } \\
\text { World Exp }\end{array}$ & $\begin{array}{c}\text { VS Share } \\
\text { of Exports }\end{array}$ & & $\begin{array}{c}\text { Countries' } \\
\text { Share of } \\
\text { World Exp }\end{array}$ & $\begin{array}{c}\text { VS Share } \\
\text { of Exports }\end{array}$ & $\begin{array}{c}\text { VS Share } \\
\text { of Exports }\end{array}$ \\
1970 & 0.60 & 0.165 & & 0.74 & 0.180 & 0.159 \\
1990 & 0.63 & 0.211 & & 0.82 & 0.236 & 0.212 \\
1995 & 0.62 & 0.222 & & 0.85 & 0.250 & 0.227 \\
& & & & & $31.3 \%$ & $33.1 \%$ \\
wth in VS: 1970 to 1990 & & $28.4 \%$ & & $38.7 \%$ & $42.6 \%$
\end{tabular}

Source: (Merchandise) export data for 1970, 1990, and 1995 is obtained from UNCTAD, Handbook of International Trade and Development Statistics

Note: VS share for each country-year is multiplied by that country-year's exports (in U.S. dollars), then the VS exports and total exports are summed across countries to obtain "world" VS and exports. World VS is divided by world exports to obtain an estimate of the world VS share. If there is no data for 1970 VS Share, we use the closest available year. Our 1995 estimates are derived as follows: for the OECD countries, we extrapolate based on growth in the VS shares between the first and last years. For the other countries, we assume that the 1995 VS share equals the VS share for the year closest to 1995.

Set 1: Includes 10 countries in OECD database + Ireland, Korea, Mexico and Taiwan. We assume VS share for Italy, Mexico, and Taiwan in 1970 is 0.2, 0.1, and 0.3, respectively. Italy estimate is based on 1970 U.K and France VS share. Mexico estimate is based on Grunwald and Flamm (1985) p.148. Taiwan estimate is based on Korea 1970 VS share.

Set 2: $\quad$ Includes Column 1 countries + Rest of Europe + Other Emerging East Asia Other Emerging East Asia includes China, Hong Kong, Indonesia, Malaysia, Singapore, and Thailand. We assume Rest of Europe (including Ireland) VS share is 0.25 in 1970, and .30 in 1990 and 1995. The rest of Europe consists primarily of small countries like Netherlands, Denmark, and Ireland, and many of these countries have recently reduced trade barriers, like Spain. We assume Emerging East Asia (including Korea and Taiwan) VS share is 0.25 in 1970 and 0.35 in 1990 and 1995. We assume the other Emerging East Asian countries have behaved like Korea and Taiwan, with a lag, except that some of these countries rely more heavily on imported inputs than do Korea and Taiwan.

Set 3: Includes Column 2 countries + Rest of World. We assume VS share for Rest of World is 0.1 in 1970, 1990, and 1995. This is based on the fact that most of the Rest of World are commodity exporters, whose share of imported inputs is relatively low. The studies cited in fn. 20 report that Ghana's cocoa exports, Zambia's copper exports, and almost all of Brazil's exports, have an imported input share of $<10 \%$. 
TABLE 6

SOURCES OF GROWTH IN VS SHARE OF TOTAL EXPORTS

VS Share of Exports

Contribution of: (percent)

\begin{tabular}{|c|c|c|c|c|c|c|}
\hline & First Year & Last Year & & $\begin{array}{l}\text { Change in industry } \\
\text { VS intensity }\end{array}$ & $\begin{array}{l}\text { Change in industry share } \\
\text { of overall exports }\end{array}$ & Total \\
\hline Australia & 0.09 & 0.11 & & & & \\
\hline Chemicals & 0.17 & 0.21 & & 4.2 & -1.6 & 2.6 \\
\hline Machinery & 0.19 & 0.23 & & 10.2 & 15.1 & 25.3 \\
\hline \multirow[t]{2}{*}{ Other } & 0.08 & 0.10 & & 64.0 & 8.2 & 72.1 \\
\hline & & & Total & 78.4 & 21.7 & 100.0 \\
\hline Canada & 0.20 & 0.27 & & & & \\
\hline Chemicals & 0.17 & 0.21 & & 1.7 & 5.1 & 6.8 \\
\hline Machinery & 0.37 & 0.44 & & 42.8 & 28.2 & 71.0 \\
\hline \multirow[t]{2}{*}{ Other } & 0.11 & 0.15 & & 29.0 & -6.9 & 22.1 \\
\hline & & & Total & 73.5 & 26.4 & 99.9 \\
\hline Denmark & 0.29 & 0.30 & & & & \\
\hline Chemicals & 0.35 & 0.33 & & -5.4 & 128.8 & 123.4 \\
\hline Machinery & 0.31 & 0.33 & & 50.7 & 86.8 & 137.5 \\
\hline \multirow[t]{2}{*}{ Other } & 0.27 & 0.27 & & 28.8 & -189.8 & -161.0 \\
\hline & & & Total & 74.1 & 25.8 & 99.9 \\
\hline France & 0.18 & 0.24 & & & & \\
\hline Chemicals & 0.21 & 0.27 & & 12.9 & 10.8 & 23.7 \\
\hline Machinery & 0.18 & 0.25 & & 38.6 & 24.3 & 62.9 \\
\hline \multirow[t]{2}{*}{ Other } & 0.17 & 0.22 & & 38.8 & -25.5 & 13.4 \\
\hline & & & Total & 90.3 & 9.6 & 100.0 \\
\hline Germany & 0.18 & 0.20 & & & & \\
\hline Chemicals & 0.24 & 0.24 & & -1.3 & -1.0 & -2.3 \\
\hline Machinery & 0.15 & 0.17 & & 91.6 & 38.0 & 129.6 \\
\hline \multirow[t]{2}{*}{ Other } & 0.22 & 0.22 & & 0.0 & -27.4 & -27.4 \\
\hline & & & Total & 90.3 & 9.6 & 99.9 \\
\hline Japan & 0.13 & 0.11 & & & & \\
\hline Chemicals & 0.12 & 0.18 & & -17.1 & 8.4 & -8.7 \\
\hline Machinery & 0.10 & 0.09 & & 11.4 & -119.1 & -107.8 \\
\hline \multirow[t]{2}{*}{ Other } & 0.18 & 0.16 & & 23.9 & 192.6 & 216.5 \\
\hline & & & Total & 18.2 & 81.9 & 100.0 \\
\hline Netherlands & 0.34 & 0.37 & & & & \\
\hline Chemicals & 0.30 & 0.42 & & 58.4 & 23.8 & 82.2 \\
\hline Machinery & 0.36 & 0.42 & & 33.0 & -40.4 & -7.4 \\
\hline \multirow[t]{2}{*}{ Other } & 0.33 & 0.34 & & 45.0 & -19.7 & 25.2 \\
\hline & & & Total & 136.4 & -36.3 & 100.0 \\
\hline United Kingdom & 0.20 & 0.26 & & & & \\
\hline Chemicals & 0.23 & 0.26 & & 8.2 & 8.8 & 17.1 \\
\hline Machinery & 0.15 & 0.29 & & 106.8 & 11.8 & 118.6 \\
\hline \multirow[t]{2}{*}{ Other } & 0.25 & 0.22 & & -4.6 & -31.1 & -35.7 \\
\hline & & & Total & 110.4 & -10.5 & 100.0 \\
\hline United States & 0.06 & 0.11 & & & & \\
\hline Chemicals & 0.05 & 0.09 & & 7.8 & 1.7 & 9.5 \\
\hline Machinery & 0.06 & 0.12 & & 60.6 & 4.3 & 64.9 \\
\hline \multirow[t]{2}{*}{ Other } & 0.06 & 0.10 & & 21.9 & 3.7 & 25.6 \\
\hline & & & Total & 90.3 & 9.7 & 100.0 \\
\hline
\end{tabular}

Source: Authors' calculations based on OECD Input-Output Datbase 
TABLE 7

SOURCES OF CROSS-COUNTRY DIFFERENCES IN VS SHARE OF TOTAL EXPORTS (FINAL YEAR)

Difference between

VS share and

VS share of representative country
Contribution of: (percent)

Difference in industry Difference in industry VS intensity

$\begin{array}{lrrr}\text { Australia } & -0.108 & 52.4 & 47.5 \\ \text { Canada } & 0.051 & 86.1 & 13.8 \\ \text { Denmark } & 0.077 & 85.3 & 14.7 \\ \text { France } & 0.020 & 70.9 & 29.1 \\ \text { Germany } & -0.024 & 134.2 & -34.2 \\ \text { Italy } & 0.049 & 68.1 & 31.9 \\ \text { Japan } & -0.110 & 92.1 & 7.9 \\ \text { Netherlands } & 0.150 & 88.3 & 11.7 \\ \text { United Kingdom } & 0.039 & 83.7 & 16.3 \\ \text { United States } & -0.112 & 103.8 & -3.8\end{array}$

Source: Authors' calculations based on OECD Input-Output Database 
TABLE 8

GROWTH IN USE OF IMPORTED INPUTS (FIRST YEAR TO LAST YEAR)

\begin{tabular}{lrr}
\hline Country & $\begin{array}{c}\text { Use in Exports } \\
\text { (percent growth) }\end{array}$ & $\begin{array}{c}\text { Use in Domestic Consumption } \\
\text { (percent growth) }\end{array}$ \\
\hline Australia & $24.8 \%$ & $12.2 \%$ \\
Canada & $35.5 \%$ & $24.2 \%$ \\
Denmark & $2.6 \%$ & $4.4 \%$ \\
France & $34.0 \%$ & $35.3 \%$ \\
Germany & $6.2 \%$ & $0.1 \%$ \\
Japan & $-18.2 \%$ & $-10.4 \%$ \\
Netherlands & $9.8 \%$ & $3.4 \%$ \\
United Kingdom & $30.1 \%$ & $7.2 \%$ \\
United States & $82.0 \%$ & $57.2 \%$ \\
& & \\
\hline
\end{tabular}

Source: Authors' calculations based on OECD Input-Output Database

\section{TABLE 9}

NORTH-SOUTH DISTRIBUTION OF VS

\begin{tabular}{|c|c|c|c|c|}
\hline \multirow{3}{*}{$\begin{array}{l}\text { Initial year } \\
\text { Country }\end{array}$} & \multicolumn{4}{|c|}{ Partner VS as a \% of total VS } \\
\hline & \multicolumn{4}{|c|}{ Origin - Destination } \\
\hline & $\mathrm{N}-\mathrm{N}$ & $\mathrm{N}-\mathrm{S}$ & $\mathrm{S}-\mathrm{N}$ & S-S \\
\hline Australia & 47.4 & 26.3 & 17.3 & 9.0 \\
\hline Canada & 87.5 & 6.6 & 5.3 & 0.6 \\
\hline Denmark & 64.6 & 15.3 & 17.3 & 2.8 \\
\hline France & 50.5 & 21.6 & 20.0 & 7.9 \\
\hline Germany & 59.1 & 18.2 & 17.2 & 5.5 \\
\hline Italy & 50.1 & 19.0 & 22.8 & 8.1 \\
\hline Japan & 29.2 & 28.5 & 20.9 & 21.3 \\
\hline Netherlands & 67.0 & 14.3 & 15.6 & 3.1 \\
\hline U.K. & 48.5 & 24.5 & 18.2 & 8.9 \\
\hline U.S. & 48.8 & 25.1 & 17.2 & 8.8 \\
\hline \multirow{3}{*}{$\begin{array}{l}\text { Final Year } \\
\text { Country }\end{array}$} & \multicolumn{4}{|c|}{ Partner VS as a \% of total VS } \\
\hline & \multicolumn{4}{|c|}{ Origin - Destination } \\
\hline & $\mathrm{N}-\mathrm{N}$ & $\mathrm{N}-\mathrm{S}$ & $\mathrm{S}-\mathrm{N}$ & S-S \\
\hline Australia & 43.1 & 27.5 & 17.0 & 12.4 \\
\hline Canada & 86.0 & 5.5 & 7.9 & 0.6 \\
\hline Denmark & 72.4 & 12.6 & 12.9 & 2.1 \\
\hline France & 62.1 & 17.3 & 16.2 & 4.4 \\
\hline Germany & 61.4 & 15.8 & 17.9 & 4.9 \\
\hline Italy & 56.3 & 16.9 & 20.5 & 6.2 \\
\hline Japan & 29.8 & 24.9 & 23.2 & 22.2 \\
\hline Netherlands & 69.5 & 9.7 & 18.5 & 2.3 \\
\hline U.K. & 66.1 & 17.2 & 13.3 & 3.4 \\
\hline U.S. & 40.7 & 22.6 & 22.6 & 14.2 \\
\hline
\end{tabular}

Source: Authors' calculations. See Appendix V. 


\section{APPENDIX I \\ Calculations and Data Sources for Intermediate Goods Trade and for Vertical Specialization}

\section{A. Intermediate Goods Trade}

Our trade data comes from the Statistics Canada World Trade Database, available from the NBER for years 1970 through 1992. This database provides bilateral trade flows for all countries and commodities, reported at the (roughly) 4-digit SITC (Revision 2) level. Additional details on this data can be found in Feenstra, Lipsey and Bowen (1997). The SITC classification does not separate goods by use, and so we employ the United Nations "Broad Economic Categories" classification scheme. The BEC organizes goods as follows.

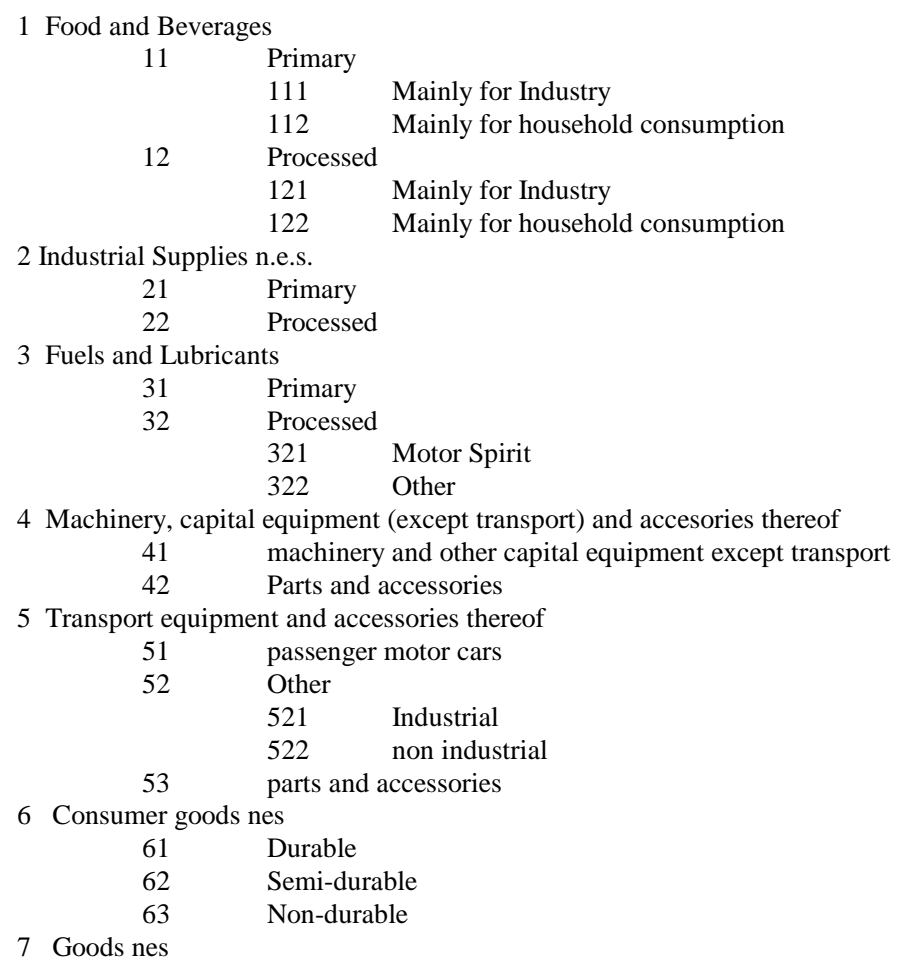

From this, goods can be aggregated into broader aggregates as follows: capital goods (41 $+521)$; intermediate goods $(111+121+2+42+53)$; consumption goods $(112+122+522+$ $6)$. In the original BEC codes, fuels trade $(31,321,322)$ is included in the intermediate goods classification. We have omitted this trade.

To match SITC rev. 2 codes to the BEC, we concord from SITC rev. 2 to SITC rev. 1 (using the concordance in Feenstra, Lipsey, and Bowen, 1997), then concord from SITC rev. 1 to the BEC codes using a mapping developed by the authors. As it is relatively easy to concord backwards from later to earlier SITC revisions, the first mapping is fairly clean. The second mapping is more problematic. While most goods map clearly into one of our three end-use categories, some are difficult to place. For example, some food products are consumed directly by consumers and as intermediate inputs into industrial food processing. These difficult to place 
goods are relatively insignificant - changing the end-use categorization for all these goods results in very little change in the overall aggregates.

\section{B. Vertical Specialization}

- Ireland: Correspondence with Central Statistics Office, Dublin, Ireland 1964: 33 sectors 1975: 41 sectors 1990: 41 sectors

- Korea: Bank of Korea, Economic Statistics Yearbook, 1993, and correspondence with Bank of Korea, Industrial Statistics Division, Seoul, Korea.

1963: 109 sectors

1990: 75 sectors

1993: 75 sectors

- Taiwan: Correspondence with Interindustrial Statistics Section, Directorate-General of Budget, Accounting and Statistics, Executive Yuan, Taipei, Taiwan.

1981: 123 sectors 1994: 150 sectors

- Mexico: (Maquiladoras): Our trade data come from Banco de Mexico (via correspondence w/ Jesus Canas of the El Paso branch of FRB Dallas), the maquiladora production, export, and imported input data come from Instituto Nacional de Estadistica, Geografia e Informatica (INEGI), also via Jesus Canas and Lucinda Vargas-Ambacher of Federal Reserve Bank, Dallas. (Non-maquiladoras): United States International Trade Commission, "Production Sharing: Use of U.S. components and Materials in Foreign Assembly Operations, 19931996", USITC Publication 3077, December 1997. 


\section{APPENDIX II \\ VSK Calculations}

Imported investment goods form part of the capital stock and provide value-added to goods that are produced in the current and ensuing years. When these goods are exported they embody the imported capital services; the value of imported capital services in exports is called VSK.

For each industry and each country in our OECD database, we construct a measure of the imported capital stock using the perpetual inventory method. Then we apply depreciation rates drawn from Jorgenson, Gollop, and Fraumeni (1987), and a rental rate that is drawn from the dividend yield of the S\&P 500. This gives us a measure of imported capital services for each industry and each year. Below, we provide more details on these calculations. We then apply (3), replacing $\mathbf{A}^{\mathbf{M}}$ with the $\mathrm{n}$ x $\mathrm{n}$ matrix $\mathbf{A}^{\mathbf{M K}}$, where element $\mathrm{ak}_{\mathrm{ij}}$ is the imported capital services from industry i used in producing industry j's output.

There are two steps to computing the imported capital services used in producing an industry's output:

1. Create imported capital stock matrices from imported investment goods matrices.

2. Calculate the imported capital service flow from the imported capital stock matrices.

\section{Creating the Imported Capital Stock Matrices.}

We begin with the imported investment goods matrices from the OECD Input-Output Database for each of the following countries and years:

1) Australia: $\quad 1986,1989$

2) Canada: $\quad$ 1971, 1976, 1981, 1986, 1990

3) Denmark: $\quad 1972,1977,1980,1985,1990$

4) France: $\quad 1972,1977,1980,1985,1990$

5) Germany: $\quad 1978,1977,1981,1986$

6) Japan: $\quad 1978,1986,1990$

7) Netherlands: $\quad 1972,1977,1981,1986$

8) U.K.: $\quad 1968,1979,1984,1990$

9) U.S.: $\quad 1972,1977,1982,1985,1990$

We denote the above matrices by $\overline{\mathrm{IKF}}_{\mathrm{k}, \mathrm{t}}^{\text {oed }}$. (Imported capital flow matrix for country $\mathrm{k}$ in year $t$ in the OECD database.)

To create the imported capital goods stock matrices, we need imported capital goods flow (or imported investment goods) matrices for all years. Since data for all years was unavailable, we imputed the imported investment goods matrices for the missing years. To do this, we first obtained the total imported capital goods flows for each of the countries for all years between 1970 and 1990 from the Statistics Canada World Trade Database (using a concordance from the 
United Nations that converts SITC codes into capital, consumption, and intermediate goods). In the years that overlapped with the OECD Input-Output database, the Statistics Canada data were typically larger than the OECD data. Consequently, for each overlapping year and country, we calculate the ratio of the total imported capital goods flow in the OECD data to the imported capital goods flow in the Statistics Canada data. For each non-overlapping year and country, we multiply the Statistics Canada imported capital data by the average of the two ratios surrounding that year. ${ }^{38}$ For each country-year prior to the earliest year of OECD data, we multiplied the Statistics Canada number by the ratio for that earliest year. This gave us annual estimates of the total imported capital goods flow for each of our nine countries for 1970-1990: $\mathrm{IK}_{\mathrm{k}, \mathrm{t}}$ For each country-year in the OECD Database, we then divide each element in the imported investment goods matrix by the total imports of investment goods:

$$
\overline{\overline{\mathrm{IKF}}}_{\mathrm{k}, \mathrm{t}}^{\text {eecd }}=\overline{\mathrm{IKF}}_{\mathrm{k}, \mathrm{t}}^{\text {oecd }} / \mathrm{IK}_{\mathrm{k}, \mathrm{t}} \text { for } \mathrm{k}, \mathrm{t} \in \mathrm{OECD} \text { database. }
$$

Each element of $\overline{\overline{\mathrm{IKF}}}_{\mathrm{k}, \mathrm{t}}^{\mathrm{oec}}, \mathrm{IKF}_{\mathrm{k}, \mathrm{t}, \mathrm{j}}^{\mathrm{oec}}$, gives the amount of imports of industry i's investment goods used to produce goods in industry $\mathrm{j}$, expressed as a share of total investment goods imports. Next, we averaged the matrices for consecutive country-years.

We can now construct the imported capital flow matrices for all country-years between 1970 and 1990 not included in the OECD Database. For each country-year falling between two years in the OECD data, the country-year's imported capital flow matrix was set equal to the estimate of the total imported capital goods flow for that year multiplied by the average of the two OECD imported capital flow matrices (expressed in share form) corresponding to the two years surrounding the country-year. For example:

$$
\overline{\mathrm{IKF}}_{\text {u.s., } 1975}=0.5 * \mathrm{IK}_{\text {u.s., } 1975} *\left(\overline{\overline{\mathrm{IKF}}}_{\text {u.s. }, 1972}^{\text {oed }}+\overline{\overline{\mathrm{IKF}}}_{\text {u.s., } 1977}^{\text {oed }}\right)
$$

If the country-year precedes the earliest year of OECD data, the country-year's flow matrix was set equal to the estimate of the total capital goods flow for that year multiplied by the average of the two OECD imported capital flow matrices (expressed in share form) corresponding to the two earliest years in the OECD database, e.g.,

$$
\overline{\mathrm{IKF}}_{\mathrm{u} . \mathrm{s}, 1971}=0.5 * \mathrm{IK}_{\mathrm{u} . \mathrm{s}, 1971} *\left(\overline{\overline{\mathrm{IKF}}}_{\mathrm{u} . \mathrm{s.}, 1972}^{\text {oed }}+\overline{\overline{\mathrm{IKF}}}_{\text {u.s., } 1977}^{\text {oed }}\right)
$$

This gave us annual estimates of the capital goods flow matrices for 1970 to 1990 .

We can now estimate the imported capital stock matrices via the perpetual inventory method:

$$
\overline{\mathrm{IKS}}_{\mathrm{k}, \mathrm{t}}=(\mathrm{I}-\bar{\delta}) * \overline{\mathrm{IKS}}_{\mathrm{k}, \mathrm{t}-1}+\overline{\mathrm{IKF}}_{\mathrm{k}, \mathrm{t}}
$$

where $\bar{\delta}$ is a diagonal matrix of industry-level depreciation rates. For all but three industries, we used the average of capital depreciation across industries, 0.13 , obtained from Jorgenson, Gollop

\footnotetext{
${ }^{38}$ For example, in the OECD data set, the imported capital flow for 1971 was 2620 million Canadian Dollars. In the Statistics Canada data, it was 3392.87 million Canadian Dollars. Dividing the OECD figure by the Statistics Canada figure for 1971 results in .7645 . For 1975 , the ratio is .7553. We averaged the two ratios to get .7759. Hence, for 1973, an in-between year, we multiplied $.7759 * 5028=3821.75$.

Note: we set the U.K. 1970 numbers equal to the data given in the 1968 U.K. matrix.
} 
and Fraumeni (1987). For the other three industries, other transport equipment, motor vehicle, and aircraft, the depreciation rate was significantly different from the average, and we used their individual depreciation rates: $0.25,0.33$, and 0.18 , respectively. We set $\overline{\mathrm{IKS}}_{\mathrm{k}, 1969}=0$.

\section{Calculating Imported Capital Services}

Because we set $\overline{\mathrm{IKS}}_{\mathrm{k}, 1969}=0$, we only used our estimated imported capital stock matrices from 1980 forward. With depreciation rates of $13 \%$, after 10 years, $80 \%$ of the initial capital stock is depreciated.

To impute the imported capital service flow for a given country-year, we multiply the imported capital stock matrices by their respective rental rates. We calculate the U.S. rental rates as follows:

$$
\overline{\mathrm{RR}}_{\mathrm{t}}=\Delta \mathrm{GDP}_{\mathrm{u.s} .}^{\mathrm{avg}}+\Delta\left(\mathrm{S} \& \mathrm{P} 500_{\mathrm{t}}\right)+\bar{\delta}
$$

For each year, the rental rate matrix is a diagonal matrix equal to the sum of the average U.S. GDP growth rate between 1970 and 1990, the increase in the S\&P 500 for that year (measuring the rate of return on capital), and the diagonal matrix of depreciation rates.

The average growth of U.S. GDP was equal to $2.7 \%$. Once again, we used delta $=0.13$ for all industries except for other transport equipment, motor vehicles, and aircraft. The estimated rental rates are listed below:

\begin{tabular}{ccccc}
\hline Year & $\begin{array}{c}\text { Rental Rates (all } \\
\text { but 3 industries) }\end{array}$ & $\begin{array}{c}\text { Other Transport } \\
\text { Equipment }\end{array}$ & Motor Vehicles & Aircraft \\
\hline 1980 & 20.78 & 32.78 & 40.78 & 25.78 \\
81 & 20.75 & 32.75 & 40.75 & 25.75 \\
82 & 21.43 & 33.43 & 41.43 & 26.43 \\
84 & 20.29 & 32.29 & 40.29 & 25.29 \\
85 & 19.87 & 31.87 & 39.87 & 24.87 \\
86 & 19.16 & 31.16 & 39.16 & 24.16 \\
89 & 18.96 & 30.96 & 38.96 & 23.96 \\
90 & 19.22 & 31.22 & 39.22 & 24.22 \\
\hline
\end{tabular}

\section{$\underline{\text { Results }}$}

Table A1 presents the VSK results. We present results for only 1980 and forward. This allows the value of the unmeasured capital stocks imported prior to 1970 to depreciate. Using our depreciation rates, in 10 years approximately $20 \%$ of the initial capital stock will be remaining. Hence, our calculations will tend to underestimate VSK. 
The numbers are not large. Only in Australia, Canada and Denmark are the VSK shares (of total exports) for 1990 above 3\%. In the U.S., for example, imported capital services used in exports accounted for only $1.4 \%$ of merchandise exports in 1990. Given the fact that imported investment goods now account for about $30 \%$ of total U.S. imports, it is surprising that VSK is such a small share of overall exports. A closer look at the input-output tables shows why. Most of the imported capital stock is used in the services industries (for example, imported motor vehicles are heavily used in the transportation services industry). Because few services are exported, the value of imported capital goods in exports will be small. In the U.S., $65.1 \%$ of the imported capital stock is used to produce services. This share is fairly uniform across countries. The variation across countries in VSK is due primarily to variation in the fraction of total investment accounted for by imports of investment goods. For example, imported investment goods in Australia are equivalent to $43.4 \%$ of total investment (in 1989). In Germany it is just $10.8 \%$, and in Japan it is just 3.0\%. Japan's imported capital VS is just $0.6 \%$ of exports.

TABLE A1

IMPORTED CAPITAL VERTICAL SPECIALIZATION EXPORTS (VSK)

\begin{tabular}{|c|c|c|c|c|c|c|c|c|}
\hline & 1980 & 1981 & 1982 & 1984 & 1985 & 1986 & 1989 & 1990 \\
\hline Australia & & & & & & $\overline{0.032}$ & $\overline{0.032}$ & \\
\hline Canada & & 0.040 & & & & 0.041 & & 0.045 \\
\hline Denmark & 0.031 & & & & 0.028 & & & 0.039 \\
\hline France & 0.014 & & & & 0.017 & & & 0.023 \\
\hline Germany & & & & & & 0.016 & & 0.018 \\
\hline Japan & 0.004 & & & & 0.005 & & & 0.006 \\
\hline Netherlands & & 0.028 & & & & 0.040 & & \\
\hline United Kingdom & & & & 0.020 & & & & 0.029 \\
\hline United States & & & 0.009 & & 0.011 & & & 0.014 \\
\hline
\end{tabular}

Source: Authors' calculations based on OECD Input-Output Database.

Note: VSK is expressed as a share of total merchandise exports 


\section{APPENDIX III \\ VS1 Calculations}

As noted in the text, VS1 captures the other half of the vertical specialization transaction. VS1 measures the exported intermediates embodied in other countries' exports. Here, we engage in two VS1 calculations. The first is a crude calculation for our entire OECD database. The second is a more careful calculation for a subset of the U.S.'s trading partners.

Our VS1 formula for a particular sector $\mathrm{i}$ and country $\mathrm{k}$ is:

$$
\text { VS1 }=\sum_{j=1}^{n}[\text { exported intermediates to country } \mathrm{j}]\left[\frac{\mathrm{j} \text { ' s exports }}{\mathrm{j} \text { ' s gross production }}\right]
$$

From (A1), it is easy to see how computing VS1 is considerably more difficult than computing VS. To compute VS1 for Japan, we would need the input-output tables of all the countries that Japan exports to. Moreover, we would also need to make assumptions about each export destination's imports from Japan relative to the export destination's imports from all other countries. For our OECD database we make three simplifications and assumptions to facilitate our calculations. First, we focus on the top export destinations, enough trading partners to ensure that more than one-third of exports is covered. We divide VS1 by total exports to these top destinations to derive an estimate of the VS1 share of exports to the world. Second, we examine only the aggregate country-level data on exports and production. Third, we assume that imported inputs from the U.S., for example, have the same composition and use in production as imports from all other countries.

In our calculations, we use the intermediates trade data described in Appendix I, the IMF's Direction of Trade Statistics bilateral trade data, the IMF's International Financial Statistics exports data, and the OECD Input-Output Databases' gross production data.

The top panel of Table A2 presents the results. VS1 as a share of exports ranges from 1\% to $8 \%$. These numbers are smaller than the VS numbers. The U.S., Germany and Netherlands are on the high end, and Australia and Canada are on the low end. It is interesting that the larger countries, with the exception of Japan, tend to have the larger VS1 shares. These countries tend to produce and export goods that are used as inputs in other countries' production processes.

For our second VS1 calculation, we focus on U.S. trade with Mexico (primarily the maquiladoras) and with Canada's motor vehicles industry. In these two cases, most intermediates exported from the U.S. become embodied in goods that are exported back to the U.S. Using data on the trade flows in both directions, and the U.S. content of Mexican maquiladora and Canadian automotive production, we are able to calculate the value of US exports that wind up embodied in US imports. Drawing from the numbers underlying Figure 4, in 1997, the U.S. content of Mexican maquiladora exports was about $\$ 35$ billion. In addition, the USITC estimates that an additional $\$ 6.4$ billion of U.S. exports to Mexican non-maquiladoras return to the U.S. embodied in Mexican goods. Drawing from the U.S.-Canada Auto Agreement case study in Hummels, Rapoport, and Yi (1998), in 1997 about \$15 billion of U.S. auto exports to Canada returned to the U.S. embodied in Canadian cars. All together, in 1997, for these two cases alone, U.S. VS1 $=\$ 56.4$ billion or equivalent to $8.2 \%$ of total U.S. merchandise exports. Doing a similar calculation for 1972, 1977, 1982, 1985, and 1990 yields the numbers in the 
bottom panel of Table A2. Most of the numbers are similar to the VS1 numbers for the U.S. listed in the top panel of Table A2, suggesting that the latter are underestimates.

TABLE A2

VS1 AS A PERCENTAGE OF TOTAL MERCHANDISE EXPORTS

\begin{tabular}{|c|c|c|c|c|c|c|}
\hline \multirow[b]{2}{*}{ Australia } & $\underline{1968}$ & $\underline{1974}$ & & $\underline{1986}$ & $\underline{1989}$ & \\
\hline & 0.035 & 0.045 & & 0.038 & 0.030 & \\
\hline & 1971 & $\underline{1976}$ & 1981 & $\underline{1986}$ & & $\underline{1990}$ \\
\hline Canada & $\overline{0.014}$ & $\overline{0.024}$ & $\overline{0.029}$ & $\overline{0.017}$ & & $\overline{0.022}$ \\
\hline & $\underline{1972}$ & $\underline{1977}$ & $\underline{1980}$ & $\underline{1985}$ & & $\underline{1990}$ \\
\hline Denmark & $\overline{0.031}$ & $\overline{0.042}$ & $\overline{0.045}$ & $\overline{0.062}$ & & $\overline{0.043}$ \\
\hline & $\underline{1972}$ & $\underline{1977}$ & $\underline{1980}$ & $\underline{1985}$ & & $\underline{1990}$ \\
\hline France & $\overline{0.042}$ & $\overline{0.058}$ & $\overline{0.063}$ & $\overline{0.070}$ & & $\overline{0.055}$ \\
\hline & & $\underline{1978}$ & & $\underline{1986}$ & 1988 & $\underline{1990}$ \\
\hline Germany & & 0.057 & & 0.049 & 0.049 & 0.050 \\
\hline & 1970 & 1975 & 1980 & 1985 & & 1990 \\
\hline Japan & $\overline{0.013}$ & $\overline{0.018}$ & $\overline{0.018}$ & $\overline{0.012}$ & & 0.016 \\
\hline & 1972 & $\underline{1977}$ & $\underline{1981}$ & $\underline{1986}$ & & \\
\hline Netherlands & $\overline{0.045}$ & $\overline{0.064}$ & $\overline{0.076}$ & $\overline{0.068}$ & & \\
\hline & & & 1979 & 1984 & & 1990 \\
\hline United Kingdom & & & 0.051 & 0.065 & & 0.048 \\
\hline & 1972 & 1977 & 1982 & 1985 & & $\underline{1990}$ \\
\hline United States & 0.050 & 0.059 & 0.061 & 0.062 & & 0.045 \\
\hline
\end{tabular}

Source: Authors' calculations based on OECD Input-Output Database.

ALTERNATIVE VS1 CALCULATION FOR U.S. BASED ON U.S.-MEXICO TRADE AND U.S.-CANADA AUTO TRADE ONLY

$\begin{array}{ll}\underline{\text { Year }} & \underline{\text { VS1 }} \\ 1972 & 0.026 \\ 1977 & 0.027 \\ 1982 & 0.028 \\ 1985 & 0.045 \\ 1990 & 0.045 \\ 1997 & 0.082\end{array}$

Source: Authors' calculations. 


\section{APPENDIX IV \\ Growth and Cross-Country Decompositions}

The growth decompositions are illustrated below. The cross-country decompositions are analogous. There are two steps to the decompositions, which employ the familiar "within" and "between" accounting:

$$
\frac{\mathrm{VS}_{\mathrm{k}, \mathrm{t}}}{\mathrm{X}_{\mathrm{k}, \mathrm{t}}}=\frac{\sum_{\mathrm{i}} \mathrm{VS}_{\mathrm{k}, \mathrm{i}, \mathrm{t}}}{\sum_{\mathrm{i}} \mathrm{X}_{\mathrm{k}, \mathrm{i}, \mathrm{t}}}=\sum_{\mathrm{i}} \omega_{\mathrm{k}, \mathrm{i}, \mathrm{t}} \frac{\mathrm{VS}_{\mathrm{k}, \mathrm{i}, \mathrm{t}}}{\mathrm{X}_{\mathrm{k}, \mathrm{i}, \mathrm{t}}}
$$

where $\mathrm{VS}_{\mathrm{k}, \mathrm{t}}$ and $\mathrm{X}_{\mathrm{k}, \mathrm{t}}$ are total VS and exports for country $\mathrm{k}$ in period $\mathrm{t}, \mathrm{VS}_{\mathrm{k}, \mathrm{i}, \mathrm{t}}$ and $\mathrm{X}_{\mathrm{k}, \mathrm{i}, \mathrm{t}}$ are country $\mathrm{k}$, industry $\mathrm{i}$ VS and exports in period $\mathrm{t}$, and $\omega_{\mathrm{k}, \mathrm{i}, \mathrm{t}}$ is country $\mathrm{k}$, industry i's share of total exports in period $t$.

Next, note that:

$$
\frac{\mathrm{VS}_{\mathrm{k}, \mathrm{t}+1}}{\mathrm{X}_{\mathrm{k}, \mathrm{t}+1}}-\frac{\mathrm{VS}_{\mathrm{k}, \mathrm{t}}}{\mathrm{X}_{\mathrm{k}, \mathrm{t}}}=\sum_{\mathrm{i}}\left(\omega_{\mathrm{k}, \mathrm{i}, \mathrm{t}+1} \frac{\mathrm{VS}_{\mathrm{k}, \mathrm{i}, \mathrm{t}+1}}{\mathrm{X}_{\mathrm{k}, \mathrm{i}, \mathrm{t}+1}}-\omega_{\mathrm{k}, \mathrm{i}, \mathrm{t}} \frac{\mathrm{VS}_{\mathrm{k}, \mathrm{i}, \mathrm{t}}}{\mathrm{X}_{\mathrm{k}, \mathrm{i}, \mathrm{t}}}\right)
$$

Equation (A.2) shows how to decompose the change in the overall VS share into industry-level changes. In the second step, we can further divide the contribution of each industry into a contribution due to changes in the industry-level VS share (within), and a contribution due to the changes in the industry-level export share (between):

$$
\begin{aligned}
& \omega_{\mathrm{k}, \mathrm{i}, \mathrm{t}+1} \frac{\mathrm{VS}_{\mathrm{k}, \mathrm{i}, \mathrm{t}+1}}{\mathrm{X}_{\mathrm{k}, \mathrm{i}, \mathrm{t}+1}}-\omega_{\mathrm{k}, \mathrm{i}, \mathrm{t}} \frac{\mathrm{VS}_{\mathrm{k}, \mathrm{i}, \mathrm{t}}}{\mathrm{X}_{\mathrm{k}, \mathrm{i}, \mathrm{t}}}= \\
& \left(\frac{\mathrm{VS}_{\mathrm{k}, \mathrm{i}, \mathrm{t}+1}}{\mathrm{X}_{\mathrm{k}, \mathrm{i}, \mathrm{t}+1}}-\frac{\mathrm{VS}_{\mathrm{k}, \mathrm{i}, \mathrm{t}}}{\mathrm{X}_{\mathrm{k}, \mathrm{i}, \mathrm{t}}}\right)\left(\frac{\omega_{\mathrm{k}, \mathrm{i}, \mathrm{t}+1}+\omega_{\mathrm{k}, \mathrm{i}, \mathrm{t}}}{2}\right)+\left(\omega_{\mathrm{k}, \mathrm{i}, \mathrm{t}+1}-\omega_{\mathrm{k}, \mathrm{i}, \mathrm{t}}\right)\left(\frac{\frac{\mathrm{VS}_{\mathrm{k}, \mathrm{i}, \mathrm{t}+1}}{\mathrm{X}_{\mathrm{k}, \mathrm{i}, \mathrm{t}+1}}+\frac{\mathrm{VS}_{\mathrm{k}, \mathrm{i}, \mathrm{t}}}{\mathrm{X}_{\mathrm{k}, \mathrm{i}, \mathrm{t}}}}{2}\right)
\end{aligned}
$$




\section{APPENDIX V \\ Geographic Orientation Calculations}

The geographic orientation of vertical specialization is constructed as follows.

1. We concord Statistics Canada trade data (all bilateral pairs, 4 digit SITC) to the 24 traded goods sectors contained in the input-output tables. The input-output tables are closely related to ISIC codes, and so this concordance is based on a mapping between SITC and ISIC codes (available from the authors on request).

2. Bilateral trade for each of our 10 countries is aggregated into OECD (north) and non-OECD (south).

3. We calculate the north and south shares of total imports in each of the 24 use sectors. In other words, we calculate north and south import shares of iron and steel sector imports used in all sectors, not import shares of all sectors used in iron and steel production. For service sector imports we assume all trade originates in or is destined for northern sources. This creates a north row vector consisting of the share of northern origin imports in every use sector (and a similar south row vector, where the column sum of these two vectors is one for every use sector).

4. We scale all values in the import use matrix $(36 \times 36)$ by the (north origin) row vector. For example, suppose north origin imports constitute $75 \%$ of intermediate imports for iron and steel. In every sector where iron and steel are used, we mutiply total use by $75 \%$, and similarly for every other imported inputs used in production. This creates a matrix of northern import use. A similar technique is used to construct southern import use. Summing the (i,j) entries for the two matrices yields back the total intermediate usage over all imports.

5. We sum over northern source import use columns to construct total imported input use for each output sector, and similarly for southern source inputs. These correspond to the intermediate import vector in equation (3).

6. We use the technique in \#3 to construct north and south export destinations for every output sector. These correspond to the exports vector in (3)

7. We perform four calculations similar to equation (3) in the text, replacing the intermediate import vector and the exports vector in (3) by a northern and southern imports and exports. This gives us four values of vertical specialization: NN, SS, NS, and SN, which we express as a fraction of total vertical specialization.

Additional note:

Some of the 24 sectors in the input-output tables are a mix of intermediate and consumption goods. The north share of total imports in a sector may be different from the north share of intermediate inputs only. To address this, in step \#3 above, we also constructed north and south shares using only intermediate and capital goods, as defined by the BEC classification scheme. This calculation yields values very similar to values calculated from total trade shares. Table 9 reports the calculations using the intermediate input shares only. 


\section{REFERENCES}

Arndt, Sven W. 1997. "Globalization and the Open Economy." North American Journal of Economics and Finance 8: 71-79.

Baer, Werner. 1995. The Brazilian Economy. $4^{\text {th }}$ ed. Westport, CN: Praeger.

Baier, Scott L. and Jeffrey H. Bergstrand. 1997. "The Growth and Regionalization of World Trade.” Unpublished manuscript, University of Notre Dame, November.

Balassa, Bela. 1967. Trade Liberalization Among Industrial Countries. New York: McGrawHill.

Barry, Frank and John Bradley. 1997. "FDI and Trade: The Irish Host-Country Experience.” The Economic Journal 107 (November): 1798-1811.

Berman Eli, John Bound, and Zvi Griliches. 1994. "Changes in the Demand for Skilled Labor within U.S. Manufacturing: Evidence from the Annual Survey of Manufactures," Quarterly Journal of Economics 109 (May): 367-98.

Campa, Jose and Linda S. Goldberg. 1997. "The Evolving External Orientation of Manufacturing: A Profile of Four Countries." Federal Reserve Bank of New York Economic Policy Review July: 53-81.

Chenery, Hollis, Sherman Robinson, and Moises Syrquin. 1987. Industrialization and Growth: A Comparative Study. New York: Oxford University Press.

Deardorff, Alan. 1979. "Weak Links in the Chain of Comparative Advantage." Journal of International Economics 9: 197-209.

Deardorff, Alan. 1998. "Fragmentation in Simple Trade Models." Manuscript, University of Michigan.

Dixit, Avinash K. and Gene M. Grossman. 1982. "Trade and Protection with Multistage Production." Review of Economic Studies 49 (October): 583-594.

Djankov, Simeon, Simon J. Evenett, and Bernard Y. Yeung. 1998. "Willingness to Pay for Tariff Liberalization.” Manuscript, World Bank, Rutgers University and University of Michigan.

Dornbusch, Rudiger, Stanley Fischer, and Paul Samuelson. 1977. "Comparative Advantage, Trade and Payments in a Ricardian Model with a Continuum of Goods." American Economic Review, 67: 823-839. 
Ethier, Wilfred J. 1982. "National and International Returns to Scale in the Modern Theory of International Trade." American Economic Review, 72: 389-405.

Feenstra, Robert C. 1998. "Integration of Trade and Disintegration of Production in the Global Economy." The Journal of Economic Perspectives. 12 (Fall): 31-50.

Feenstra, Robert C., Robert E. Lipsey, and Harry P. Bowen. 1997. "World Trade Flows, 19701992, with Production and Tariff Data.” NBER Working Paper No. 5910, January.

Feenstra, Robert C. and Gordon H. Hanson. 1997. "Foreign Direct Investment and Relative Wages: Evidence from Mexico's Maquiladoras.” Journal of International Economics 42 (May): 371-394.

Feenstra, Robert C. and Gordon H. Hanson. 1996. "Foreign Investment, Outsourcing and Relative Wages.” In R.C. Feenstra, G.M. Grossman and D.A. Irwin, eds., The Political Economy of Trade Policy: Papers in Honor of Jagdish Bhagwati. MIT Press: Cambridge, MA, 89-127.

Findlay, Ronald. 1978. "An Austrian Model of International Trade and Interest Rate Equalization.” Journal of Political Economy 86: 989-1008.

Freund, Caroline. 1998. "Regionalism and Permanent Diversion.” International Finance Discussion Paper \#602, Board of Governors of the Federal Reserve System.

Grossman, Gene and Elhanan Helpman. 1995. “The Politics of Free Trade Agreements." American Economic Review 85 (September): 667-690.

Grunwald, Joseph, and Kenneth Flamm. 1985. The Global Factory: Foreign Assembly in International Trade. Washington, D.C.: Brookings.

Hummels, David. 1998a. "Towards a Geography of Trade Costs.” Manuscript, University of Chicago.

Hummels, David. 1998b. "Transportation Costs and the Growth of World Trade." Manuscript, University of Chicago.

Hummels, David, Dana Rapoport, and Kei-Mu Yi. 1998. "Vertical Specialization and the Changing Nature of World Trade." Federal Reserve Bank of New York Economic Policy Review June: 79-99.

Ishii, Jun, and Kei-Mu Yi. 1997. "The Growth of World Trade.” Federal Reserve Bank of New York Research Paper no. 9718, May.

Jones, Ronald W. and Henryk Kierzkowski. 1990. "The Role of Services in Production and International Trade: A Theoretical Framework." In R. Jones and A. Krueger, eds., The 
Political Economy of International Trade. Cambridge, MA: Basil Blackwell, 1990.

Jones, Ronald W. and Henryk Kierzkowski. 1997. "Globalization and the Consequences of International Fragmentation." Manuscript. University of Rochester and Graduate Institute of International Studies, Geneva.

Jorgenson, Dale, Frank Gollop, and Barbara Fraumeni. 1987. Productivity and U.S. Economic Growth. Cambridge, MA: Harvard University Press.

Krugman, Paul R. 1992. “Is Bilateralism Bad?” In E. Helpman and A. Razin, eds., International Trade and Trade Policy. MIT Press: Cambridge, MA, 9-24.

Krugman, Paul R. 1995. "Growing World Trade: Causes and Consequences." Brookings Papers on Economic Activity, 1: 327-77.

Lawrence, Robert. 1994. “Trade, Multinationals, and Labor.” NBER Working Paper No. 4836, August.

Markusen, James R. 1997. “Trade Versus Investment Liberalization.” Unpublished paper, University of Colorado, August.

Rose, Andrew. 1991. "Why Has Trade Grown Faster than Income?" Canadian Journal of Economics 24, no. 2: 417-27.

Organization for Economic Cooperation and Development. 1995. The OECD Input-Output Database. Paris: Organization for Economic Cooperation and Development.

Pearson, Scott R. and John Cownie. 1974. Commodity Exports and African Economic Development. Lexington, MA: D.C. Heath and Co.

Sanyal, Kalyan K. 1983. "Vertical Specialization in a Ricardian Model with a Continuum of Stages of Production." Economica. 50: 71-78.

Sanyal, Kalyan K., and Ronald W. Jones. 1982. "The Theory of Trade in Middle Products." American Economic Review 72, no. 1: 16-31.

Slaughter, Mathew J. 1995. "Multinational Corporations, Outsourcing, and American Wage Divergence." NBER Working Paper No. 5253.

Szereszewski, Robert. 1966. “The Sectoral Structure of the Economy, 1960.” In W. Birmingham, I. Neustadt, and E.N. Omaboe, eds., The Economy of Ghana. Northwestern University Press: Evanston, IL, 62-88.

United Nations Conference on Trade and Development. 1997. Handbook of International Trade and Development Statistics 1995. New York: United Nations. 
U.S. International Trade Commission. 1997. "Production Sharing: Use of U.S. Components and Materials in Foreign Assembly Operations, 1993-1996," USITC Publication 3077. Washington, D.C.: U.S. International Trade Commission.

Yeats, Alexander J. 1998. "Just How Big is Global Production Sharing?" Manuscript, World Bank.

Yi, Kei-Mu. 1999. "The Growth of World Trade: A Dynamic Model of Vertical Specialization" In process, Federal Reserve Bank of New York. 